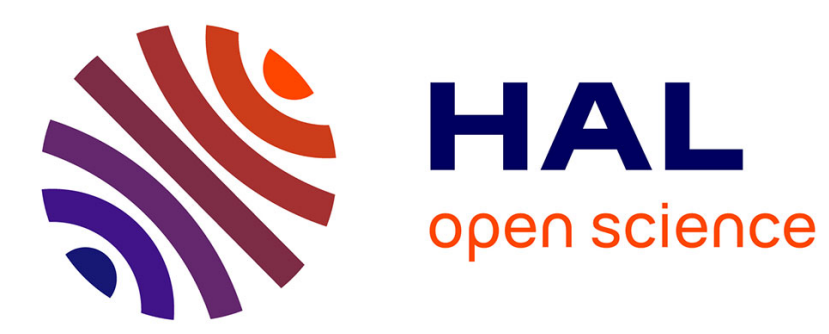

\title{
NO reduction capacity of four major solid fuels in reburning conditions : experiments and modeling
}

Julien Cances, Jean-Michel Commandre, Sylvain Salvador, Philippe Dagaut

\section{To cite this version:}

Julien Cances, Jean-Michel Commandre, Sylvain Salvador, Philippe Dagaut. NO reduction capacity of four major solid fuels in reburning conditions: experiments and modeling. Fuel, 2008, 87 (3), p.274-289. 10.1016/j.fuel.2007.05.011 . hal-01845773

\section{HAL Id: hal-01845773 \\ https://hal.science/hal-01845773}

Submitted on 6 Nov 2018

HAL is a multi-disciplinary open access archive for the deposit and dissemination of scientific research documents, whether they are published or not. The documents may come from teaching and research institutions in France or abroad, or from public or private research centers.
L'archive ouverte pluridisciplinaire HAL, est destinée au dépôt et à la diffusion de documents scientifiques de niveau recherche, publiés ou non, émanant des établissements d'enseignement et de recherche français ou étrangers, des laboratoires publics ou privés. 


\title{
NO reduction capacity of four major solid fuels in reburning conditions - Experiments and modeling
}

\author{
Julien Cancès ${ }^{\mathrm{a}, *}$, Jean-Michel Commandré ${ }^{\mathrm{a}}$, Sylvain Salvador ${ }^{\mathrm{a}}$, Philippe Dagaut ${ }^{\mathrm{b}}$ \\ ${ }^{a}$ Laboratoire de Génie des Procédés des Solides Divisés, UMR-CNRS 2392, Ecole des Mines d'Albi-Carmaux, Campus Jarlard, \\ 81013 Albi CT Cedex 09, France \\ ${ }^{\mathrm{b}}$ Laboratoire de Combustion et Systèmes Réactifs, 1C, Avenue de la Recherche Scientifique, 45071 Orleans Cedex 2, France
}

\begin{abstract}
The combustion of solid fuels in the rotary kiln and in the calciner of a cement plant generates fuel and thermal NO. This NO can be reduced inside the reducing zone of the calciner. This occurs in two different ways: homogeneous reduction by hydrocarbons and heterogeneous reduction by char. The purpose of this paper is to identify the relative contribution of volatile matters or char on the NO reduction process, which largely depends on the nature of the solid fuel used for reburning.

Experiments were undertaken in an Entrained Flow Reactor (EFR), at three temperatures: 800, 900 and $1000^{\circ} \mathrm{C}$. Four major fuels used in the cement production process were studied: a lignite, a coal, an anthracite and a petcoke. Specific experiments were undertaken to determine (i) their devolatilisation kinetics and the gas species released. A wide range of species influencing the NO chemistry was carefully analyzed. Then, (ii) the char oxidation and (iii) the char NO reduction kinetics were characterized. Finally, (iv), the "global" NO reduction capability of each fuel was quantified through experiments during which all phenomena could occur together. This corresponds to the situation of an industrial reactor in reducing conditions. Anthracite and petcoke reduce only very small quantities of NO whereas lignite and coal reduce, respectively, $90 \%$ and $80 \%$ of the initially present $880 \mathrm{ppm}$ of $\mathrm{NO}$ (at $1000{ }^{\circ} \mathrm{C}$ after $2 \mathrm{~s}$ ).

The four types of experiments described above were then modeled using a single particle thermo-chemical model that includes heterogeneous reactions and detailed chemistry in the gas phase. This model reveals that both NO reduction on char and NO reduction by volatiles mechanisms contribute significantly to the global NO reduction. After short residence times (several tenth of a second), gas phase reactions reduce NO efficiently; after long residence times (several seconds) the char reduces larger quantities of NO.
\end{abstract}

Keywords: Reburning; Solid fuels; Nitric oxides formation/reduction; Experimental; Numerical model

\section{Introduction}

The combustion of coal leads to $\mathrm{NO}_{\mathrm{x}}$ emissions, contributing to acid rain and photochemical fog. The necessity for $\mathrm{NO}_{\mathrm{x}}$ reduction is internationally recognized and effective control technologies have been developed [1]. Combustion produces mainly $\mathrm{NO}\left(90-95 \%\right.$ of the total amount of $\mathrm{NO}_{\mathrm{x}}$ produced) which subsequently oxidizes at ambient temperature into $\mathrm{NO}_{2}[2,3]$. Solid fuel combustion mainly induces the production of Fuel-NO ( $>90 \%$ of the NO produced) [4-6], resulting from the oxidation of the nitrogen com-

\footnotetext{
* Corresponding author.

E-mail address: cances@enstimac.fr (J. Cancès).
}

pounds of the fuel. This tendency is further increased in the case of a cement plant calciner, where the "low" temperature $\left(<1300^{\circ} \mathrm{C}\right)$ prevents thermal $\mathrm{NO}_{\mathrm{x}}$ formation $[2,7]$.

The production of Portland cement is the result of numerous reactions happening at different temperatures $[1,2,8,9]$ :

- first, the main ingredient of cement (calcite or $\mathrm{CaCO}_{3}$ (75-80\%)) should be calcined in the temperature range $800-1000^{\circ} \mathrm{C}$ to yield lime $(\mathrm{CaO})$; this reaction mainly occurs in the calciner;

- second, the lime and other cement components of clinker are sintered within the rotary kiln at high temperature $\left(1300-1450{ }^{\circ} \mathrm{C}\right)$ : these are the clinkering reactions; 
- then, the clinker is rapidly cooled to obtain the desired crystalline structure.

Due to the high combustion temperature of the rotary kiln, both thermal and fuel NO are produced there.

In the calciner, either in the so-called "combustion chamber" or downstream of the rotary kiln, secondary fuel is injected, creating a fuel-rich zone, also called the "reducing zone". It has been observed that substantial NO reduction occurs in this zone, where the conditions are similar to those of the "reburning" process.

Reburning consists of adding fuel, frequently natural gas, downstream of the primary burning zone, creating a fuel-rich zone that reduces $\mathrm{NO}_{\mathrm{x}}$, by up to $80 \%$ [4]. Some applications where pulverized coal is used as reburning fuel are presented in the literature [4,10-12] showing good NOreduction efficiency.

When pulverized coal is injected, devolatilisation occurs, releasing a large variety of gaseous species. Those species are mainly $\mathrm{CO}, \mathrm{CO}_{2}, \mathrm{H}_{2}, \mathrm{CH}_{4}$ and other aliphatic or cyclic hydrocarbons, widely studied in the literature [13-18]. Nitrogen species, $\mathrm{HCN}$ and $\mathrm{NH}_{3}[10,19,20]$, or $\mathrm{SO}_{2}$ [2] are also released. The interactions between $\mathrm{NO}$ and the gaseous species present in the volatile matters (VMs) have been widely studied [21-29].

In the case of coal reburning, the influence of NO reduction at the char surface [6,30-32] has also a major influence on the global NO reduction. Fig. 1 represents schematically the main mechanisms that form and reduce NO simultaneously during the combustion/reburning process. At the present time, the relative contribution of volatile matters and char on the NO reduction process is not fully understood $[32,33]$.

In an increasing number of applications, coal is replaced by alternative solid fuels. The most important ones are lig-

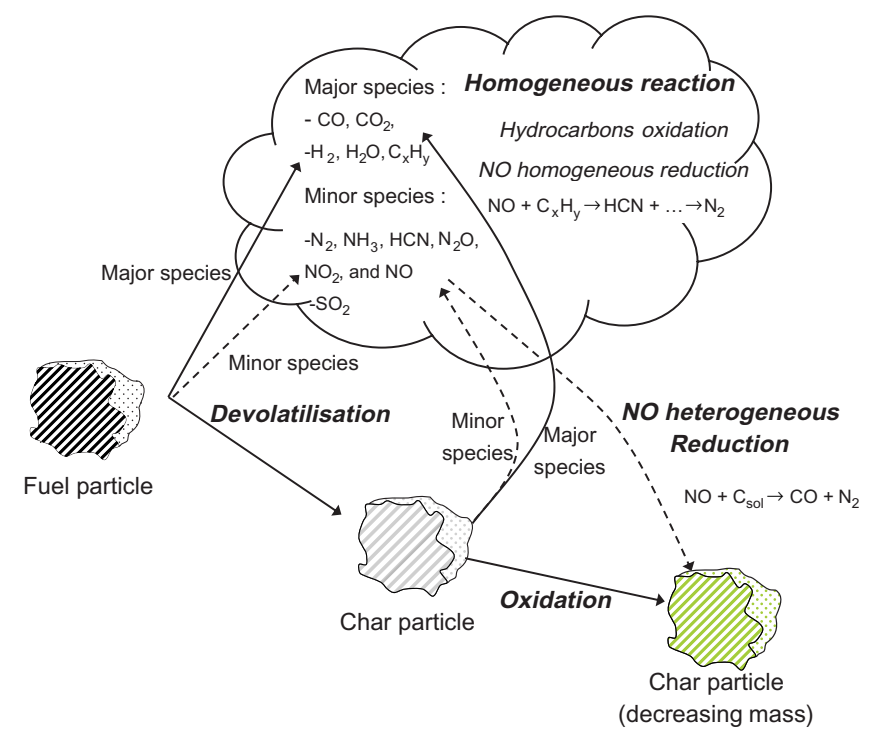

Fig. 1. General representation of the mechanisms forming and reducing NO. nite, anthracite and petcoke. Coal reburning has been extensively studied. However, the NO reduction capacity of these alternative fuels has not been characterized previously. The purpose of this work is to determine the relative importance of these homogeneous and heterogeneous phenomena in the case of the four major fuels used in the cement production process. To reach this goal, both experiments and modelings were carried out for the four fuels.

The experiments were performed on an Entrained Flow Reactor (EFR), that allows the fuel injection into industrial furnaces to be reproduced in the laboratory [2,34]. This reactor permits the temperature and atmosphere gas concentrations to be set to the desired value. The modeling is achieved thanks to a single particle thermo-chemical model [35] that has been improved for the present work. The particle devolatilisation and the gaseous species released are taken into account. The gas phase reactions - which were not characterized experimentally in this work - were computed by CHEMKIN II subroutines [36] using the detailed mechanism of [23] (145 species, 1006 reactions). The char oxidation and NO reduction by char are also computed.

The thermo-chemical conditions for this work are representative of those in the reducing zone of a cement plant calciner $[1,2,8]$ : particle residence time of $2 \mathrm{~s}$, flow temperature of $900{ }^{\circ} \mathrm{C}$, presence of $1.5 \% \mathrm{O}_{2}$ and $880 \mathrm{ppm} \mathrm{NO}$.

In a first step, the three elementary heterogeneous reactions occurring in the reburning process were characterized in term of reaction kinetics. These mechanisms are:

- devolatilisation; the nature and quantities of the released gaseous species were also characterized;

- char oxidation;

- NO reduction on char.

To achieve this, three series of specific experiments were carried out to characterize these solid/gas reactions. In each series, the three temperatures 800,900 , and $1000{ }^{\circ} \mathrm{C}$ were operated. The modeling of each experiment at each temperature was then performed to adjust the different parameters of the model for each fuel.

In a second step, the reburning situation where all the reactions happen simultaneously - representative of the situation which occurs in cement plant calciners - was reproduced in experiments. It was then modeled using the kinetic parameters previously determined. At this stage, no more parameters were adjusted in the model.

This modeling finally enables a detailed analysis of the contributions of the different mechanisms involved in the NO reduction.

\section{Experimental}

\subsection{Experimental set-up}

All the experiments were performed in a device specifically set up to achieve the combustion of pulverized solid 


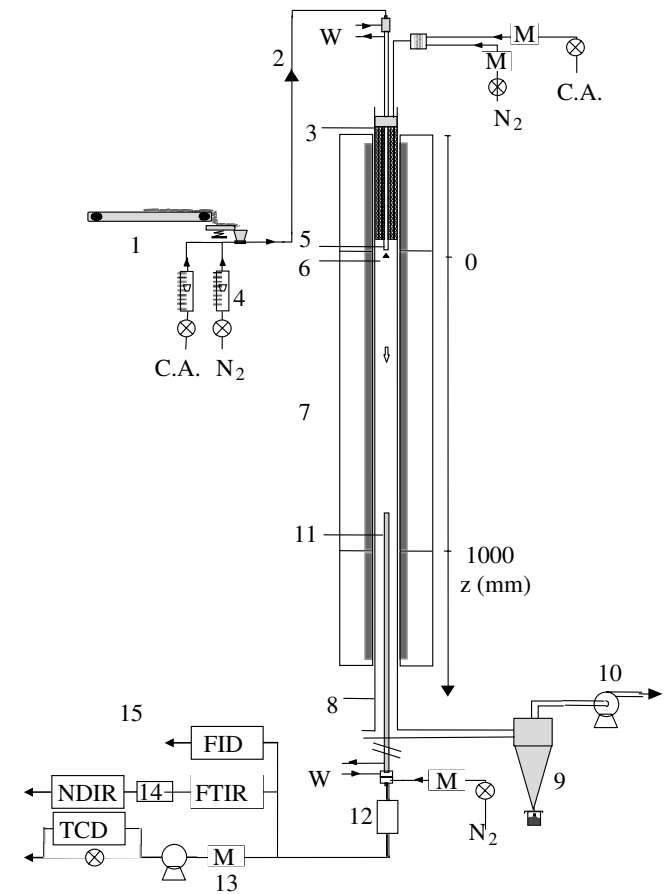

Fig. 2. Schematic view of the Entrained Flow Reactor of Ecole des Mines d'Albi [37,38]. (1) Conveyor belt, vibrating corridor, ejector; (2) pneumatic transport; (3) electrical preheater; (4) flow meters; (5) water-cooled feeding probe; (6) dispersion dome; (7) three-zone electrical furnace; (8) $80 \mathrm{~mm}$ i.d quartz tube reactor; (9) cyclone collector; (10) exhaust fan; (11) water cooled sampling probe; (12) particle collector (filter); (13) sampling pump; (14) gas conditioner; (15) gas analyzers (NDIR, param., FTIR, FID, TCD); (M) mass flow meters and controllers; $\left(\mathrm{N}_{2}\right)$ nitrogen; (C.A.) compressed air; (W) water (probes cooling).

fuels under "flash" conditions, typical of those in a fluidized bed or in a cement plant calciner. The apparatus consisted of an EFR whose design details have been fully described before [34,37]. The apparatus is shown in Fig. 2. It is an $80-\mathrm{mm}$ i.d. $1-\mathrm{m}$ long isothermal quartz reactor fed with an electrically preheated laminar atmosphere gas flow. To create the desired mixture of gases, the different gas flow rates were controlled by precise mass flow meters/controllers. The powdered solid fuel is injected through a water-cooled feeding probe and dispersed over the cross-section of the reactor. It reacts for a controlled residence time before being sampled by a water-cooled probe [38]. The well controlled solid injection consists of a low velocity $(10 \mathrm{~cm} / \mathrm{min})$ conveyor belt that ensures a fuel mass flow rate from 0.5 to $1.5 \mathrm{~g} / \mathrm{min}$. The belt is fed from a separately prepared V-shaped rail along which a precisely weighted quantity of fuel is regularly spread using a calibrated wedge. The gas and solid phases can be collected at different heights $(z)$ using a water-cooled sampling probe, allowing precise control of the particles and gas residence time. After sampling and separating gas from particles, the gases are forwarded to the analyzers, via a Teflon heated line. The sampled gases were distributed towards four continuous analyzer types:
- a fourier transform infra-red (FTIR) analyser to quantify continuously $\mathrm{NO}, \mathrm{NO}_{2}, \mathrm{~N}_{2} \mathrm{O}, \mathrm{NH}_{3}, \mathrm{HCN}, \mathrm{CO}$, $\mathrm{CO}_{2}, \mathrm{CH}_{4}, \mathrm{C}_{2} \mathrm{H}_{2}, \mathrm{C}_{2} \mathrm{H}_{4}, \mathrm{C}_{2} \mathrm{H}_{6}, \mathrm{C}_{3} \mathrm{H}_{8}, \mathrm{C}_{6} \mathrm{H}_{6}$ and $\mathrm{SO}_{2}$;

- a non-dispersive infra-red (NDIR) analyzer for $\mathrm{CO}$, $\mathrm{CO}_{2}, \mathrm{SO}_{2}, \mathrm{NO}$ and $\mathrm{NO}_{\mathrm{x}}$ concentrations and a paramagnetic analyzer for $\mathrm{O}_{2}$ concentration;

- two flame ionization detectors (FIDs) for $\mathrm{CH}_{4}$ and total hydrocarbons (THCs);

- a thermal conductivity detector (TCD) for $\mathrm{H}_{2}$.

During the experiments, the atmosphere gas introduced into the reactor and the reactor walls were heated to the controlled temperature. The atmosphere gas with controlled concentrations was fed in at a flow rate of $16 \mathrm{~L} /$ min STP. The transport nitrogen flow rate was set to $2.55 \mathrm{~L} / \mathrm{min}$ STP. The reference particle mass flow rate was $1.5 \mathrm{~g} / \mathrm{min}$. To achieve satisfactory averaging of the concentrations over a cross-section of the reactor, the total flow rate at the suction of the sampling probe was $12 \mathrm{~L} / \mathrm{min} \mathrm{STP}$.

\subsection{Properties of the fuels}

The four different fuels used in the experiments represent most commonly used fuels in the energy production domain, particularly in cement industry for petcoke $[2,34]$ :

- a lignite;

- a bituminous coal;

- an anthracite;

- a petcoke.

The properties of these fuels are presented in Table 1. The proximate and ultimate analysis values were obtained following French standards NF M 03-003 for the ash [39], NF M 03-004 [40] for the volatile and NF M 03-002 [41] for the moisture contents. The fixed carbon $\left(\mathrm{C}_{\mathrm{fix}}\right)$ and oxygen contents were calculated by difference.

Two of these fuels, lignite and coal, have a high volatile content (52 and $35 \mathrm{wt} \%$, respectively), whereas anthracite and petcoke are very low-volatile fuels (6 and $7 \mathrm{wt} \%$ ). The nitrogen content of the fuels is comprised between 1.1 and $1.7 \mathrm{wt} \%$, apart from lignite where $\mathrm{N}$-content is low: $0.4 \mathrm{wt} \%$. The two high-volatile fuels have a high oxygen content: $24.9 \mathrm{wt} \%$ for lignite and $16.2 \mathrm{wt} \%$ for coal, whereas anthracite and petcoke only contain 4.4 and $6.8 \mathrm{wt}^{\mathrm{\%}} \%$ oxygen, respectively.

Prior to any analysis or experiments, the four fuels were ground, dried, and the fraction $30-100 \mu \mathrm{m}$ was selected by pneumatic sieving. After this treatment, the particle size was similar for the four fuels, and would not be responsible for any difference observed along the combustion/reburning process.

\subsection{Production and characterization of the chars}

\subsubsection{Chars production}

The chars used to determine the kinetic parameters for char oxidation and NO reduction at the char surface were 
Table 1

Fuels physicochemical analysis

\begin{tabular}{|c|c|c|c|c|c|c|c|c|c|c|}
\hline \multirow[t]{2}{*}{ Fuel name } & \multicolumn{5}{|c|}{ Proximate analysis } & \multicolumn{4}{|c|}{ Ultimate analysis } & \multirow[t]{2}{*}{$\mathrm{LCV}(\mathrm{MJ} / \mathrm{kg})$} \\
\hline & Moisture (wt\%) & $\mathrm{VM}\left(\mathrm{wt}^{0} \%\right)$ & $\operatorname{Ash}\left(w t^{0} \%\right)$ & $\mathrm{C}_{\text {fix }}(\mathrm{wt} \%)$ & $\mathrm{C}(\mathrm{wt} \%)$ & $\mathrm{H}(\mathrm{wt} \%)$ & $\mathrm{N}(w \mathrm{t} \%)$ & $\mathrm{S}(\mathrm{wt} \%)$ & $\mathrm{O}(\mathrm{wt} \%)$ & \\
\hline Lignite & 4.73 & 51.50 & 8.66 & 35.11 & 59.28 & 5.07 & 0.42 & 1.72 & 24.85 & 26.70 \\
\hline Coal & 3.46 & 34.76 & 11.60 & 50.18 & 65.27 & 4.77 & 1.71 & 0.45 & 16.20 & 25.91 \\
\hline Anthracite & 0.63 & 5.50 & 6.32 & 87.55 & 84.91 & 2.75 & 1.12 & 0.46 & 4.44 & 30.77 \\
\hline Petcoke & 1.82 & 6.84 & 0.5 & 90.84 & 83.30 & 1.85 & 1.59 & 5.93 & 6.83 & 32.76 \\
\hline
\end{tabular}

The values for fixed carbon $\left(\mathrm{C}_{\mathrm{fix}}\right)$ in proximate analysis and $\mathrm{O}$-atoms in ultimate analysis were both calculated by difference.

themselves produced in the EFR. Indeed, their physicochemical properties strongly depend on the preparation conditions, and particularly on the heating rate. The chars were produced in the following conditions:

- the atmosphere temperature was set to $900{ }^{\circ} \mathrm{C}$;

- the atmosphere gas was $\mathrm{N}_{2}$ and 3 vol $\% \mathrm{O}_{2}$.

The total atmosphere gas flow rate was $18.55 \mathrm{~L} / \mathrm{min}$ STP; the fuel particle feeding rate was $1.5 \mathrm{~g}_{\text {Fuel }} / \mathrm{min}$ transported by a $2.55 \mathrm{~L} / \mathrm{min}$ STP nitrogen flow. The resulting particle residence time was $2 \mathrm{~s}$.

The average temperature of $900{ }^{\circ} \mathrm{C}$ was adopted to prepare the chars devoted to all further experiments (at 800, 900 and $1000{ }^{\circ} \mathrm{C}$ ). In the narrow range of temperature $\left(800-1000^{\circ} \mathrm{C}\right)$, the heating rate for the particles would be in the same order of magnitude as in the case of $900^{\circ} \mathrm{C}$, and the properties of the chars would be similar. Indeed, Mermoud et al. [42] have shown that significant differences in the properties of the chars are observed only if the heating rate is changed by one order of magnitude or more.

The $3 \%$ oxygen concentration was set to oxidize the volatile matters, particularly tars, and prevent them from condensing at the char surface. This phenomenon was observed experimentally by Pillet [3] and suggested by Solomon et al. [16]. In our case, tar condensation at the char surface was also observed in case of pyrolysis under pure nitrogen of high-volatile fuels (lignite and coal). The ESEM photographs presented in [43] clearly show carbon concretions at the char surface. Due to this observation, it was decided to set the concentration of oxygen to $3 \% \mathrm{O}_{2}$, a value that was successfully applied by Commandré et al. [2,31,44].

\subsubsection{Chars characterization}

The physicochemical properties of the collected chars are presented in Table 2. Due to the low ash content of some fuels and the small available quantities of chars, the char ash content was determined using a TGA device under air, where the final temperature was set to $815^{\circ} \mathrm{C}$ (as in the case of standard tests). The skeletal density, $\rho_{\text {pycno, was }}$ characterized using He-pycnometry. The specific surface,

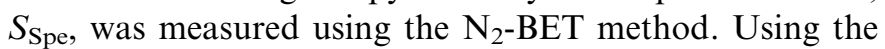
total specific surface - as measured from BET using $\mathrm{N}_{2}-$ to characterize the char reactive surface is the classical reference method, despite it is known that the total porous surface is not the actual reactive surface $[31,42,44]$. This is open to research to determine the actual reactive surface of a porous carbon. The porosity, $\varepsilon$, was characterized with $\mathrm{Hg}$-porosimetry. Note that the porosity of lignite char could not be measured because the highly porous and fragile sample was crushed by high pressure of mercury during measurements; we assumed that this porosity is equal to that of coal char.

\section{Numerical modeling}

The model used for this study is based on a thermochemical model developed by Commandré et al. [35] to describe the combustion of powdered fuels in EFR conditions (laminar flow). It takes into account the thermal and chemical mechanisms which occur during the combustion. The formation and reduction mechanisms for fuel NO, prompt NO, and thermal NO are modeled.

The basic assumption of the model is that the EFR is a one dimensional plug flow reactor fed with a preheated gas flow (air or $\mathrm{N}_{2}$ ) and a mono dispersed cold solid particles flow which is homogeneously dispersed in the gas flow. The whole flow is simulated considering a single particle and the gas volume that can be associated with it. The assumption of no particle interactions is implicitly made. The particles are assumed to be isothermal.

Table 2

Chars physicochemical analysis

\begin{tabular}{|c|c|c|c|c|c|c|c|c|c|}
\hline \multirow[t]{2}{*}{ Fuel name } & \multirow[t]{2}{*}{ Ash $\left(\mathrm{wt}^{0} \%\right)$} & \multicolumn{5}{|c|}{ Ultimate analysis } & \multicolumn{3}{|c|}{ Physical properties } \\
\hline & & $\mathrm{C}(\mathrm{wt} \%)$ & $\mathrm{H}(\mathrm{wt} \%)$ & $\mathrm{N}(\mathrm{wt} \%)$ & $\mathrm{S}(\mathrm{wt} \%)$ & $\mathrm{O}(\mathrm{wt} \%)$ & $\overline{\rho_{\text {pycno }}\left(\mathrm{kg} / \mathrm{m}^{3}\right)}$ & $\varepsilon(\%)$ & $S_{\text {Spe }}\left(\mathrm{m}^{2} / \mathrm{kg}\right)$ \\
\hline Lignite & 16.33 & 65.47 & 1.35 & 0.93 & 2.36 & 13.46 & 1760 & - & 123 \\
\hline Coal & 17.48 & 71.18 & 1.2 & 1.97 & 0.16 & 8.03 & 1700 & 68.2 & 4.4 \\
\hline Anthracite & 7.42 & 86.01 & 1.87 & 1.00 & 0.36 & 4.72 & 1950 & 14.2 & 27.5 \\
\hline Petcoke & 1.61 & 88.37 & 1.31 & 1.52 & 6.23 & 0.96 & 1630 & 3.4 & 3.7 \\
\hline
\end{tabular}

$\mathrm{O}$-atoms in ultimate analysis was calculated by difference. 


\subsection{Particle properties}

The particles are taken as spherical with a diameter of $65 \mu \mathrm{m}$ (mean value of $30-100 \mu \mathrm{m}$ ). It is assumed that the diameter is constant during the combustion. The particle is assumed to be isothermal, and its temperature is computed through a heat balance including conductive heat exchange with the gas phase, radiative heat exchange with the furnace wall and heat source terms from heterogeneous reactions. The heat capacity of the particles, char and ashes are, respectively, assumed to be 1200, 1900 and $1900 \mathrm{~J} \mathrm{~kg}^{-1} \mathrm{~K}^{-1}$. The tortuosity of the porous particle is assumed to be equal to 4 .

The particle composition is initially described in terms of $\mathrm{C}, \mathrm{H}, \mathrm{O}, \mathrm{N}, \mathrm{S}$ and ash mass percentages. The mass of each component is computed during the reaction at each time step. $\mathrm{N}$ and $\mathrm{S}$ are released through different gas species both during pyrolysis and char oxidation. The $\mathrm{N}$ and $\mathrm{S}$ remaining in the char are released during oxidation proportionally to the mass loss: the mass fractions of $\mathrm{N}$ and $\mathrm{S}$ in the char do not change along the process. This behavior is detailed using partitioning coefficients adjusted by fitting the model to the experimental values.

\subsection{Devolatilisation}

A lot of work was done by different authors during the 1980 s to describe the devolatilisation process [13$16,19,45,46]$. The purpose of this work was not to achieve a fine description of the devolatilisation, but to describe correctly the VM release observed in experiments. Thus, the devolatilisation kinetics was described using a simple mathematical model - single pseudo-Arrhenius law - which does not have the capability to compute heating rate or pressure effects, this because all experiments and modeling work was realized at atmospheric pressure and with the high heating rate corresponding to the flash conditions in our reactor. Indeed this reactor was designed with the aim to reproduce particles heating rates encountered in calciners or powdered fuel burners. Other authors used this rough assumption because of its simplicity and its relatively good accuracy with global experimental results $[2,47]$. The devolatilisation reaction is described following expressions:

$\frac{\partial m_{\text {Fuel }}}{\partial t}=-k_{\mathrm{dev}} \cdot m_{\text {Fuel }}$
$\frac{\partial m_{\mathrm{Vol}}}{\partial t}=\alpha_{\mathrm{dev}} \cdot k_{\mathrm{dev}} \cdot m_{\text {Fuel }}$
$k_{\mathrm{dev}}=A_{\mathrm{dev}} \cdot \exp \left(-\frac{E a_{\mathrm{dev}}}{R T}\right)$

The activation energy was set at $110 \mathrm{~kJ} \mathrm{~mol}^{-1}$ for all fuels, corresponding to a value commonly found in the literature $[2,34,48,49]$. The pre-exponential factor $A_{\text {dev }}$ (Eq. (3)) was adjusted by a minimization on the experimental values at the three temperatures: 800,900 and $1000{ }^{\circ} \mathrm{C}$. A different

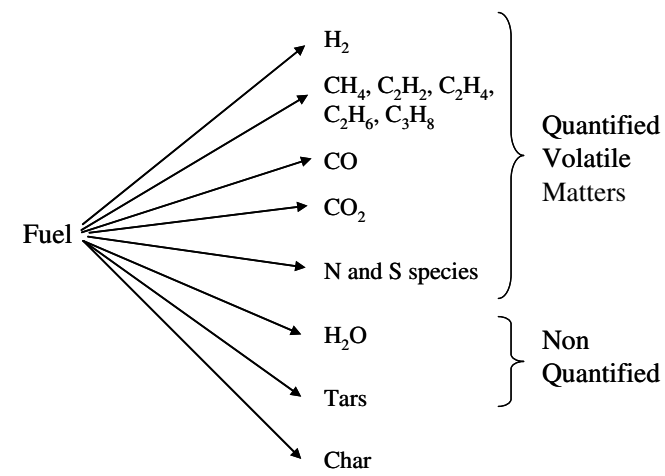

Fig. 3. Mass partitioning of fuel during devolatilisation.

value of the VM mass fraction, $\alpha_{\mathrm{dev}}$, is determined at each experimental temperature.

The partitioning of the initial mass of the fuel during devolatilisation is illustrated in Fig. 3. In this model, tars - that represent approximately half of the mass of volatile matters as shown further - are assumed to have the same composition as char, and to behave as the char residue regarding their oxidation and participation to $\mathrm{NO}$ chemistry.

Another assumption was that $\mathrm{H}$ and $\mathrm{O}$ atoms that are not recovered after analysis of pyrolysis gases and chars were assumed to form water, i.e. not to play a role in the pollutants chemistry. These assumptions remain weak points in the proposed approach, and should motivate further research in these domains.

Thus, as illustrated in Fig. 3, the volatile matters modeled are assumed to be composed of

- major species - carbon oxides $\left(\mathrm{CO}, \mathrm{CO}_{2}\right)$, hydrogen, and hydrocarbons $\left(\mathrm{CH}_{4}, \mathrm{C}_{2} \mathrm{H}_{2}, \mathrm{C}_{2} \mathrm{H}_{4}, \mathrm{C}_{2} \mathrm{H}_{6}, \mathrm{C}_{3} \mathrm{H}_{8}\right)$,

- minor species - nitrogen species $\left(\mathrm{NO}, \mathrm{N}_{2} \mathrm{O}, \mathrm{NH}_{3}\right.$, $\mathrm{HCN}$ ), and $\mathrm{SO}_{2}$.

The mass of each formed volatile and solid species is computed as detailed below:

- At first, the mass of $\mathrm{N}$ and $\mathrm{S}$ containing species is calculated.

Establishing the $\mathrm{N}$ mass balance described in Fig. 4, the mass of each $\mathrm{N}$ containing species can be calculated first through the partition coefficient $\alpha_{N}$ that distinguishes between $\mathrm{N}$ in volatile species and $\mathrm{N}$ remaining in the char.

- volatile $\mathrm{N}$ is distributed among $\mathrm{NO}, \mathrm{N}_{2} \mathrm{O}, \mathrm{HCN}$ and $\mathrm{NH}_{3}$ thanks to the partitioning coefficients $\eta_{\mathrm{v}}, \beta_{\mathrm{v}}, \delta_{\mathrm{v}}$ and $\varepsilon_{\mathrm{v}}$, respectively. Their values were determined by fitting the model to experimental values. The $\mathrm{N}$ balance is closed through $\gamma_{\mathrm{v}}$, assuming that the remaining $\mathrm{N}$ atoms are converted to $\mathrm{N}_{2}$.

- $\mathrm{N}$ in char and tars is distributed among $\mathrm{NO}, \mathrm{N}_{2} \mathrm{O}, \mathrm{HCN}$ and $\mathrm{NH}_{3}$ resulting from later char oxidation thanks to the partitioning coefficients $\eta_{\mathrm{c}}, \beta_{\mathrm{c}}, \delta_{\mathrm{c}}$ and $\varepsilon_{\mathrm{c}}$, respectively. 

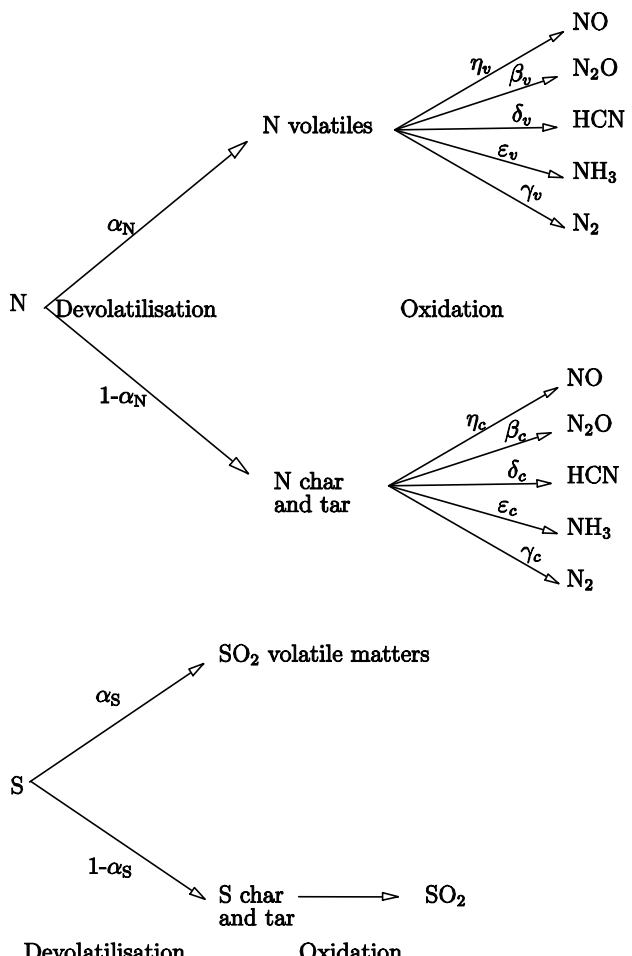

Fig. 4. Fate of $\mathrm{N}$ and $\mathrm{S}$ elements during devolatilisation and char oxidation.

Again the $\mathrm{N}$ balance is closed thanks to $\gamma_{\mathrm{c}}$, assuming that the remaining $\mathrm{N}$ is converted to $\mathrm{N}_{2}$.

The mass balance for $\mathrm{S}$ species proposed in Fig. 4 assumes that part of the fuel sulfur is released during devolatilisation to form $\mathrm{SO}_{2}$ only. The partitioning coefficient $\alpha_{\mathrm{S}}$ is determined by fitting the model with devolatilisation experiments. The $\mathrm{S}$ atoms remaining in char and tar are converted later on to $\mathrm{SO}_{2}$, along the char oxidation reaction.

- A mass balance for $\mathrm{O}$ atoms is represented in Fig. 5. The $\mathrm{O}$ atoms are supposed to devolatilise into $\mathrm{CO}$ and $\mathrm{CO}_{2}$, with the partitioning coefficients $\alpha_{\mathrm{O} \rightarrow \mathrm{CO}}$ and $\alpha_{\mathrm{O} \rightarrow \mathrm{CO}_{2}}$, respectively, both determined by fitting the model with devolatilisation experiments. A negligible amount of $\mathrm{O}$ is used to form $\mathrm{N}$ species.

- The mass of the last volatile species can be calculated from the $\mathrm{H}$ balance as illustrated in Fig. 5. $\mathrm{H}$ atoms are released as hydrocarbons (i.e. $\mathrm{CH}_{4}, \mathrm{C}_{2} \mathrm{H}_{2}, \mathrm{C}_{2} \mathrm{H}_{4}$, $\mathrm{C}_{2} \mathrm{H}_{6}, \mathrm{C}_{3} \mathrm{H}_{8}$ ) and $\mathrm{H}_{2}$, with the partitioning coefficients $\alpha_{\mathrm{H} \rightarrow \mathrm{CH}_{4}}, \quad \alpha_{\mathrm{H} \rightarrow \mathrm{C}_{2} \mathrm{H}_{2}}, \quad \alpha_{\mathrm{H} \rightarrow \mathrm{C}_{2} \mathrm{H}_{4}}, \quad \alpha_{\mathrm{H} \rightarrow \mathrm{C}_{2} \mathrm{H}_{6}}, \quad \alpha_{\mathrm{H} \rightarrow \mathrm{C}_{3} \mathrm{H}_{8}}, \quad$ and $\alpha_{\mathrm{H} \rightarrow \mathrm{H}_{2}}$, respectively. These partitioning coefficients are set by fitting the model with pyrolysis experiments. A negligible amount of $\mathrm{H}$ is used to form $\mathrm{N}$ and $\mathrm{S}$ containing species;

- Finally, the mass balance for $\mathrm{C}$ established in Fig. 5 enables to calculate the mass of char. The mass of tar is included in the mass of char, as discussed previously.
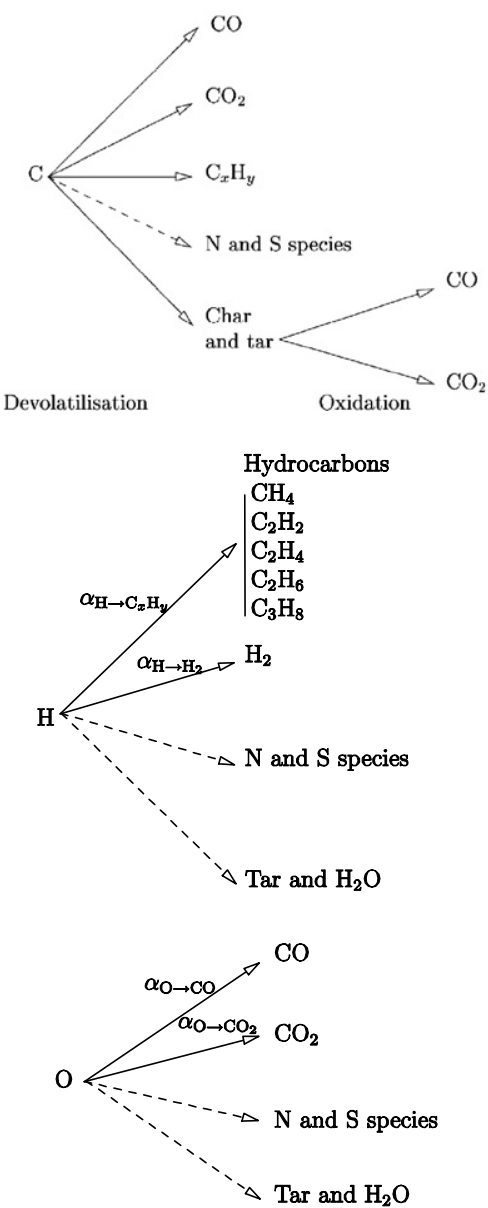

Fig. 5. Fate of $\mathrm{C}, \mathrm{H}$ and $\mathrm{O}$ elements during devolatilisation.

The values for all partitioning coefficients were determined thanks to specific experiments (devolatilisation (Type 1) and char oxidation (Type 2)) as detailed further in the paper. They were gathered together in Table 3.

\subsection{Heterogeneous reactions}

Both char oxidation and NO reduction are calculated in this computer code. In both cases, the internal and external mass transfer limitations in the porous particle are taken into account.

\subsubsection{Char oxidation}

The char oxidation reaction into $\mathrm{CO}$ and $\mathrm{CO}_{2}-$ the major species - is represented by the following reaction:

$\mathrm{C}_{\mathrm{s}}+\left(1-\frac{f r_{\mathrm{CO}}}{2}\right) \mathrm{O}_{2} \rightarrow \mathrm{fr}_{\mathrm{CO}} \mathrm{CO}+\left(1-f r_{\mathrm{CO}}\right) \mathrm{CO}_{2}$

where $\mathrm{fr}_{\mathrm{CO}}$ is the mole fraction of $\mathrm{CO}$ released during char oxidation, determined following the Arthur's law (5):

$\frac{n_{\mathrm{CO}}}{n_{\mathrm{CO}_{2}}}=2500 \exp \left(-\frac{51,843}{R T}\right)$ 


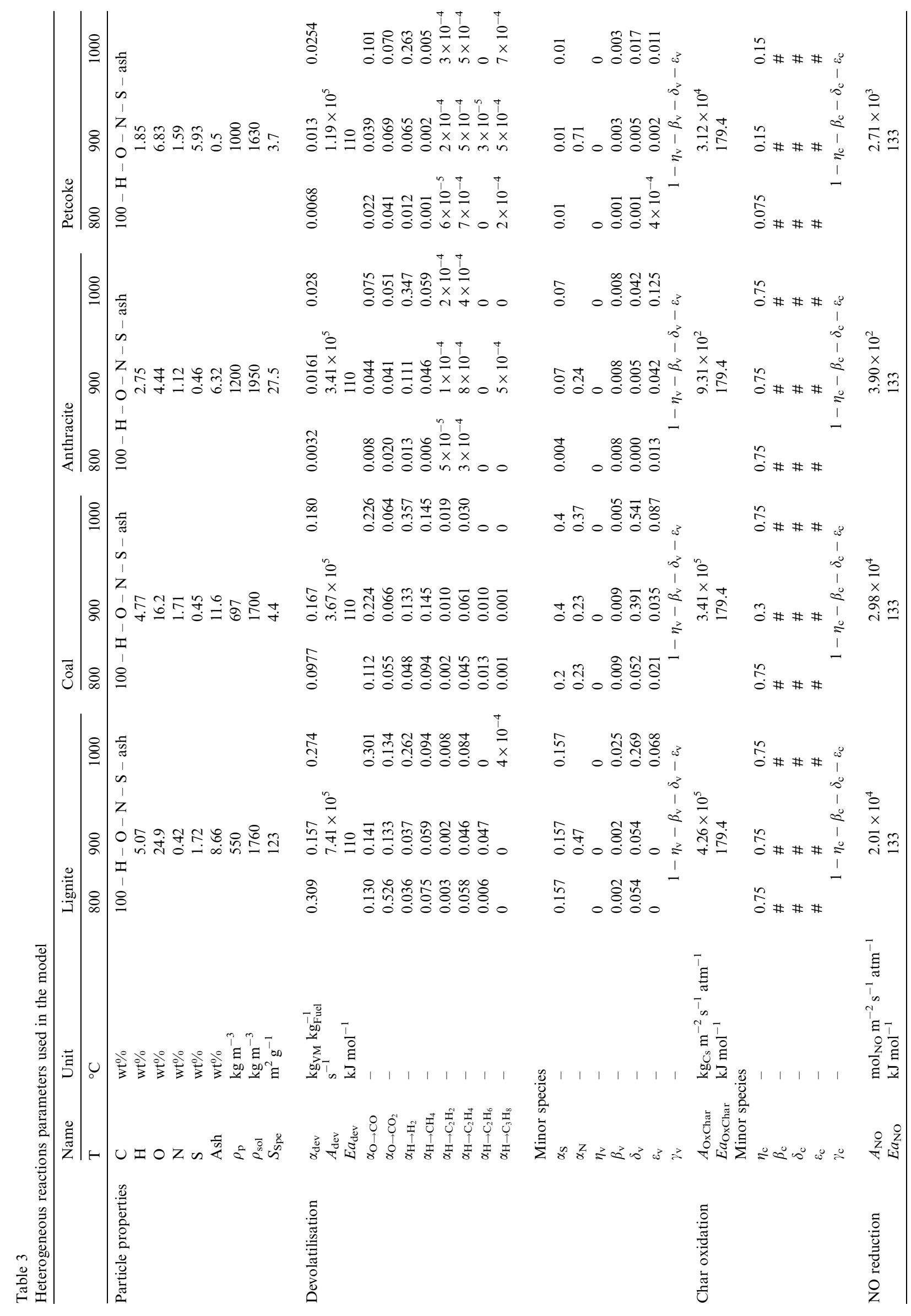


The kinetics of the char oxidation is modeled following a single pseudo Arrhenius law (6)

$$
\begin{aligned}
& \frac{\partial m_{\mathrm{Char}, \mathrm{Ox}}}{\partial t}=-\eta \cdot k_{\mathrm{OxChar}} \cdot S_{\mathrm{Spe}} \cdot m_{\mathrm{Char}} \cdot P_{\mathrm{O}_{2}}^{n} \\
& k_{\text {OxChar }}=A_{\text {OxChar }} \exp \left(-\frac{E a_{\text {OxChar }}}{R T}\right)
\end{aligned}
$$

where $m_{\text {Char }}$ is the mass of char $(\mathrm{kg})$ in the considered volume element, $\eta$ is the effectiveness factor (dimensionless), $S_{\text {Spe }}$ the specific surface area $\left(\mathrm{m}^{2} / \mathrm{kg}\right), P_{\mathrm{O}_{2}}$ is oxygen partial pressure at the surface of the particle (atm) and $n$ is the reaction's order (dimensionless). $A_{\text {OxChar }}$ is the pre-exponential factor of the kinetic law $\left(\mathrm{kg}_{\mathrm{C}} \mathrm{m}^{-2} \mathrm{~s}^{-1} \mathrm{~atm}^{-1}\right)$ and $E a_{\text {OxChar }}$ is the activation energy for char oxidation $(\mathrm{J} / \mathrm{mol})$. In the present work, $E a_{\text {OxChar }}$, was set to the Smith value of $179.4 \mathrm{~kJ} / \mathrm{mol}$ [50] and $A_{\text {OxChar }}$ is adjusted through a minimization of the difference between the experimental results obtained at the three temperatures 800, 900 and $1000{ }^{\circ} \mathrm{C}$ and model computed values.

The reaction order, $n$, varies in the literature between 0.5 and $1[9,50,51]$. Smith [50] uses a unity value for temperatures higher than $1000 \mathrm{~K}$ and 0.5 for lower temperatures. In this work $n$ is assumed to be equal to 1 .

The effectiveness factor can then be calculated by means of the pore model initially proposed by Thiele for porous catalysts applications [52] and further adapted by Smith to char oxidation $[50,51]$. This model is reminded and detailed in [53].

During char oxidation, some minor species $-\mathrm{SO}_{2}$ and nitrogen species ( $\mathrm{NO}, \mathrm{N}_{2} \mathrm{O}, \mathrm{NH}_{3}, \mathrm{HCN}$ ) - are also released. Respectively, the $\alpha_{\mathrm{S}}$ and the $\eta_{\mathrm{c}}, \beta_{\mathrm{c}}, \delta_{\mathrm{c}}$ and $\varepsilon_{\mathrm{c}}$ partitioning coefficients make it possible to describe the release of these species (see Fig. 4). They were adjusted to fit the experimental values obtained in devolatilisation (Type 2) experiments; the determined numerical values are presented in Table 3.

\subsubsection{NO reduction at the char surface}

The NO reduction at the char surface is assumed to follow the reaction (8).

$\mathrm{C}_{\mathrm{s}}+\mathrm{NO} \rightarrow \mathrm{CO}+1 / 2 \mathrm{~N}_{2}$

The rate of NO consumption by char is computed assuming the expression (9) that follows a first order Arrhenius law (10).

$$
\begin{aligned}
& r_{\mathrm{NO}, \mathrm{Char}}=-\eta_{\mathrm{NO}} \cdot k_{\mathrm{NO}} S_{\mathrm{Spe}} \cdot m_{\mathrm{Char}} \cdot P_{\mathrm{NO}}^{m} \\
& k_{\mathrm{NO}}=A_{\mathrm{NO}} \exp \left(-\frac{E a_{\mathrm{NO}}}{R T}\right)
\end{aligned}
$$

The effectiveness factor relative to the NO reduction by char, $\eta_{\mathrm{NO}}$, is computed following the same method as for char oxidation. The reaction's order, $m$, is assumed to be unity as it is outlined in the literature [2,31,54]. $A_{\mathrm{NO}}$ is the pre-exponential factor $\left(\mathrm{mol}_{\mathrm{NO}} \mathrm{m}^{-2} \mathrm{~s}^{-1} \mathrm{~atm}^{-1}\right)$ and $E a_{\mathrm{NO}}$ is the activation energy that was set to the value proposed by Aarna and Suuberg [54] and confirmed by
Commandré et al. [31]: $133 \mathrm{~kJ} / \mathrm{mol}$. In the minimization process, only the pre-exponential factor $A_{\mathrm{NO}}$ was adjusted to match the experimental data. The determined kinetic parameters for the NO reduction by char are presented in Table 3.

\subsection{Gas phase reactions}

Gas phase reactions, are treated with the Dagaut et al. scheme (145 species, 1006 reactions) [23]. This detailed mechanism allows interactions between NO and hydrocarbons (from $\mathrm{H}_{2}$ to $\mathrm{C}_{4}$ ) to be correctly described, taking the influence of $\mathrm{SO}_{2}$ into account. The reaction rates and energy source terms are treated by CHEMKIN II [36] software subroutines that are called upon by the main program.

\section{Results}

\subsection{Experimental and modeling strategy}

Let us remind the main mechanisms that form and reduce NO during the combustion/reburning as illustrated in Fig. 1. The three heterogeneous reactions - devolatilisation, char oxidation and NO reduction by char, in bold in Fig. 1 - were studied successively. The kinetic parameters and all the partitioning coefficients presented above were adjusted by comparing the results of the successive modeling to the experimental data for each heterogeneous mechanism.

In order to model the reburning process, four different types of experiment and modeling were carried out.

\section{Type 1: fuel devolatilisation}

These experiments consisted in injecting a powdered fuel in pure $\mathrm{N}_{2}$ atmosphere and sampling after different residence times. The objectives were:

- to determine the kinetic parameters of the devolatilisation reaction;

- to determine the variety of species released during devolatilisation;

- to determine all the partitioning coefficients related to the devolatilisation presented above $\left(\alpha_{\mathrm{N}}, \alpha_{\mathrm{S}}, \eta_{\mathrm{v}}, \beta_{\mathrm{v}}, \delta_{\mathrm{v}}\right.$, $\varepsilon_{\mathrm{v}}, \quad \gamma_{\mathrm{v}}, \quad \alpha_{\mathrm{O} \rightarrow \mathrm{CO}}, \quad \alpha_{\mathrm{O} \rightarrow \mathrm{CO}_{2}}, \quad \alpha_{\mathrm{H} \rightarrow \mathrm{CH}_{4}}, \quad \alpha_{\mathrm{H} \rightarrow \mathrm{C}_{2} \mathrm{H}_{2}}, \quad \alpha_{\mathrm{H} \rightarrow \mathrm{C}_{2} \mathrm{H}_{4}}$, $\alpha_{\mathrm{H} \rightarrow \mathrm{C}_{2} \mathrm{H}_{6}}, \alpha_{\mathrm{H} \rightarrow \mathrm{C}_{3} \mathrm{H}_{8}}$, and $\left.\alpha_{\mathrm{H} \rightarrow \mathrm{H}_{2}}\right)$.

\section{Type 2: char oxidation}

As illustrated in Fig. 1, the char oxidation consumes the char residue and is responsible for the direct formation of some gaseous $\mathrm{N}$-species. Along this process, char also reduces $\mathrm{NO}$ in the gas phase.

The experiments to characterize this reaction consisted in injecting chars - previously prepared - in an atmosphere containing $3 \% \mathrm{O}_{2}$ in $\mathrm{N}_{2}$. The value of $3 \% \mathrm{O}_{2}$ was selected to obtain high enough char burnout for accurate determination to be reached, on the base of $\mathrm{O}_{2}$ consumption measurements. Samples were taken after a 2 s particle residence time. 
Type 3: reduction of NO by char

The purpose of these experiments was to determine the kinetic parameters of the reduction of NO by char. Such type of experiments has already been described in $[2,31]$. The chars - previously prepared - were injected in an atmosphere containing $880 \mathrm{ppm} \mathrm{NO}$ in $\mathrm{N}_{2}$. This value of 880 ppm NO was chosen as a typical concentration in the reducing zone of the calciner. The particle residence time was $2 \mathrm{~s}$.

\section{Type 4: reburning by solid fuels}

Finally, Type 4 experiments were carried out. These experiments aim at reproducing the situation of $\mathrm{NO}$ reburning by a solid fuel as it happens in the reducing zone of a calciner. In this situation, all the phenomena described above occur together, including gas phase oxidation of hydrocarbons and interactions between NO and VM.

The predictions of the model, in which the parameters determined from Type 1, Type 2 and Type 3 experiments were included, are compared with experimental results. No more parameters were adjusted at this stage of the modeling procedure. Therefore the model was then used to investigate the contribution of the different chemical mechanisms to NO formation and reduction.

In these experiments a fuel was injected in an atmosphere containing $1.5 \% \mathrm{O}_{2}$ and $880 \mathrm{ppm} \mathrm{NO}$ in $\mathrm{N}_{2}$. These
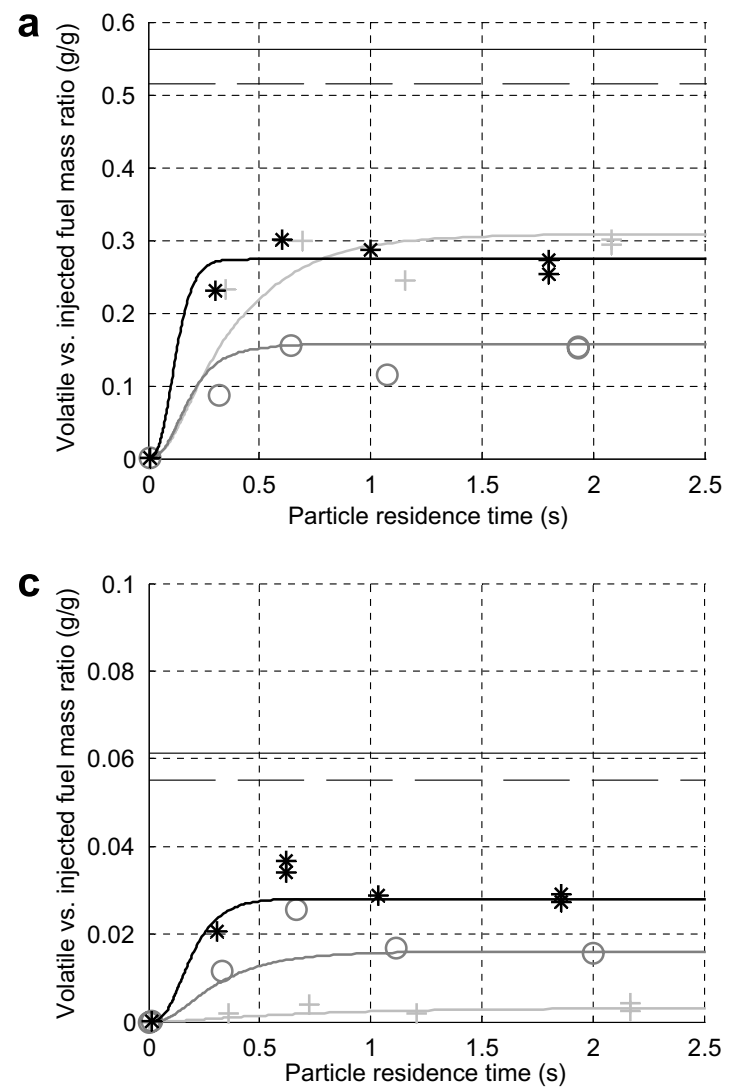

values are representative for typical $\mathrm{O}_{2}$ and $\mathrm{NO}$ concentrations in the reducing zone of a cement plant calciner. The residence time was $2 \mathrm{~s}$, as in Type 2 and Type 3 experiments. In these conditions, the overall oxidation stoichiometry considering the whole solid fuel is very rich for the four fuels: $0.09<$ equivalence ratio $<0.11$.

It was shown that $\mathrm{O}_{2}$ must be present for homogeneous $\mathrm{NO}$ reduction reactions by hydrocarbons to occur. Indeed oxygenated radicals such as $\mathrm{O}, \mathrm{OH}$, and $\mathrm{HCCO}$ have a great influence on the reduction mechanism $[21-23,29,55]$. Nevertheless, if $\mathrm{O}_{2}$ is present in too large quantities, hydrocarbons are rapidly oxidized and cannot reduce NO. Consequently, there exists an optimum value for the concentration in $\mathrm{O}_{2}$; this value depends on the thermochemical conditions. Kinetic gas-phase studies have clearly demonstrated that TFN (the total fixed nitrogen, i.e. the overall concentration of $\mathrm{N}$-compounds except $\mathrm{N}_{2}$ ) is minimized in conditions of slight excess air $(1<$ equivalence ratio $<1.2)[22]$.

\subsection{Characterization of the elementary heterogeneous reactions}

\subsubsection{Type 1: Fuel devolatilisation}

4.2.1.1. Devolatilisation kinetics. The traditional ash tracer method was not used here to determine the fuel mass loss
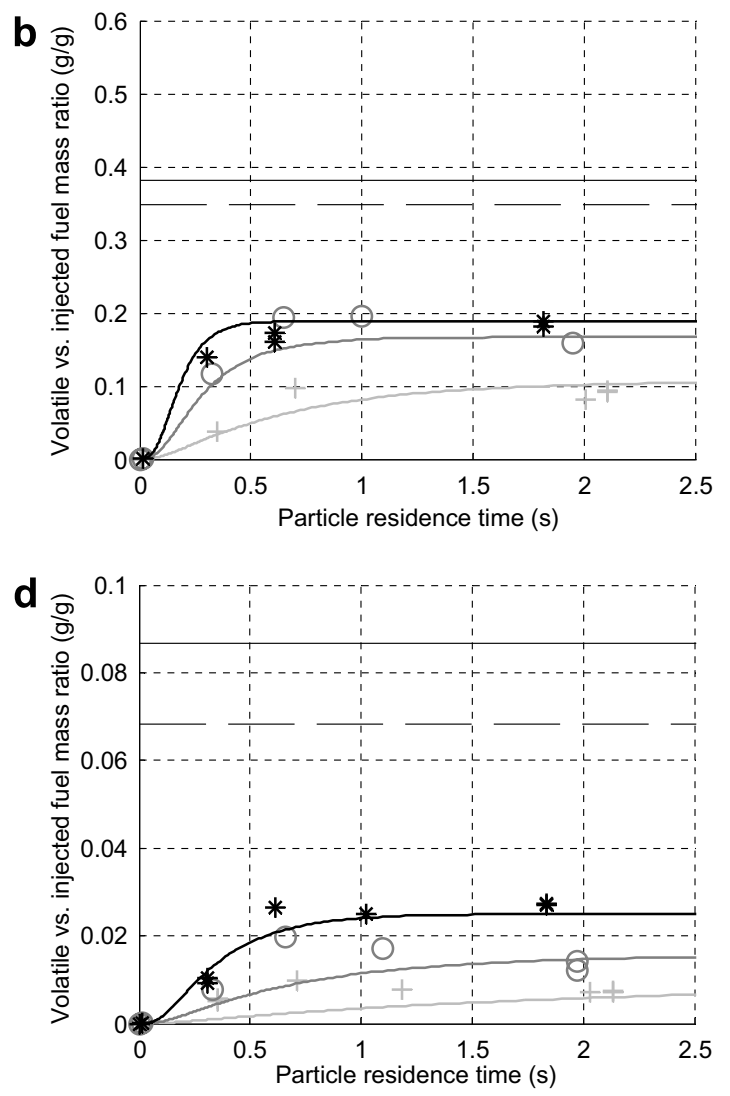

Fig. 6. Fuels devolatilisation: time evolution of the sum of measured gas masses normalized to the initial fuel mass at different temperatures. Symbols: experiments $\left(+: 800{ }^{\circ} \mathrm{C}, \bigcirc: 900^{\circ} \mathrm{C}, *: 1000^{\circ} \mathrm{C}\right)$; bold curves: model results $\left(\ldots, 800{ }^{\circ} \mathrm{C}, \ldots, 900{ }^{\circ} \mathrm{C}, \ldots, 1000^{\circ} \mathrm{C}\right)$; thin black lines: standard test values $\left(\_\right.$, VM content; ----, excluding moisture). (a) Lignite; (b) coal; (c) anthracite; and (d) petcoke. 
because the ash content of petcoke and anthracite is too low (see Table 1). As a consequence, the kinetic parameters were derived from the time evolution of the total mass of volatile matters analyzed during experiments.

The total mass flow rate for all the VM analyzed has been calculated and plotted for the four fuels in Fig. 6. It should be noted that the data are normalized to the initial fuel mass injected into the EFR. The full scale in ordinate is $0.6 \mathrm{~g}_{\mathrm{VM}} / \mathrm{g}_{\text {Fuel }}$ for lignite and coal (Fig. 6a and b) and $0.1 \mathrm{~g}_{\mathrm{VM}} / \mathrm{g}_{\text {Fuel }}$ for anthracite and petcoke (Fig. 6c and $\mathrm{d}$ ). The amount represented on these diagrams as a straight dotted line corresponds to the standard VM content after subtracting moisture; it is always larger than the sum of the species analyzed. This is due to the fact that several species were not measured in the experimental device. The results indicate that half or more of the VM mass was not identified despite the large number of species analyzed in this work. In the following of the paper, the strong assumption will be made that this mass - consisting essentially of tars - is $\mathrm{C}_{\mathrm{s}}$, since it is the dominant component of tars. Indeed, chemical reaction schemes to describe gas phase tars interactions with NO are still not available, and taking these reactions into account in the model cannot be undertaken. In the model, tars implicitly participate to NO heterogeneous reduction as if they were char. They are assumed to oxidize at the same rate as char.
For the low VM content fuels - anthracite and petcokethe final mass of VM released increases when the devolatilisation temperature increases from 800 to $1000{ }^{\circ} \mathrm{C}$. Surprisingly, this typical behavior is not retrieved in the case of lignite.

The fitted devolatilisation kinetic parameters are presented in Table 3. It is interesting to note that the pre-exponential factor increases when the fuel rank decreases (for this work, we consider that petcoke is a high rank fuel: it has a low volatile amount and low $\mathrm{O}$ - and $\mathrm{H}$-contents).

Fig. 6 shows that the model can satisfactorily describe the release of VM over time, although significant differences remain at certain points.

\subsubsection{Released species}

We have plotted in Fig. 7 the time variation of the mole fraction of each species in VM during experiments at $1000{ }^{\circ} \mathrm{C}$ for the lignite, the coal, the anthracite and the petcoke. The temperature of $1000{ }^{\circ} \mathrm{C}$ was chosen for the plots because this temperature is closer to other processes than cement plants. The values lower than $10 \mathrm{ppm}$ should not be considered since they are below the detection limit of the analyzers. It appears clearly that $\mathrm{H}_{2}$ is the main species (in moles) released during pyrolysis in all cases. $\mathrm{CO}$ and $\mathrm{CO}_{2}$ are also important, as well as $\mathrm{CH}_{4}$ which is always the major hydrocarbon species. Other species are mainly
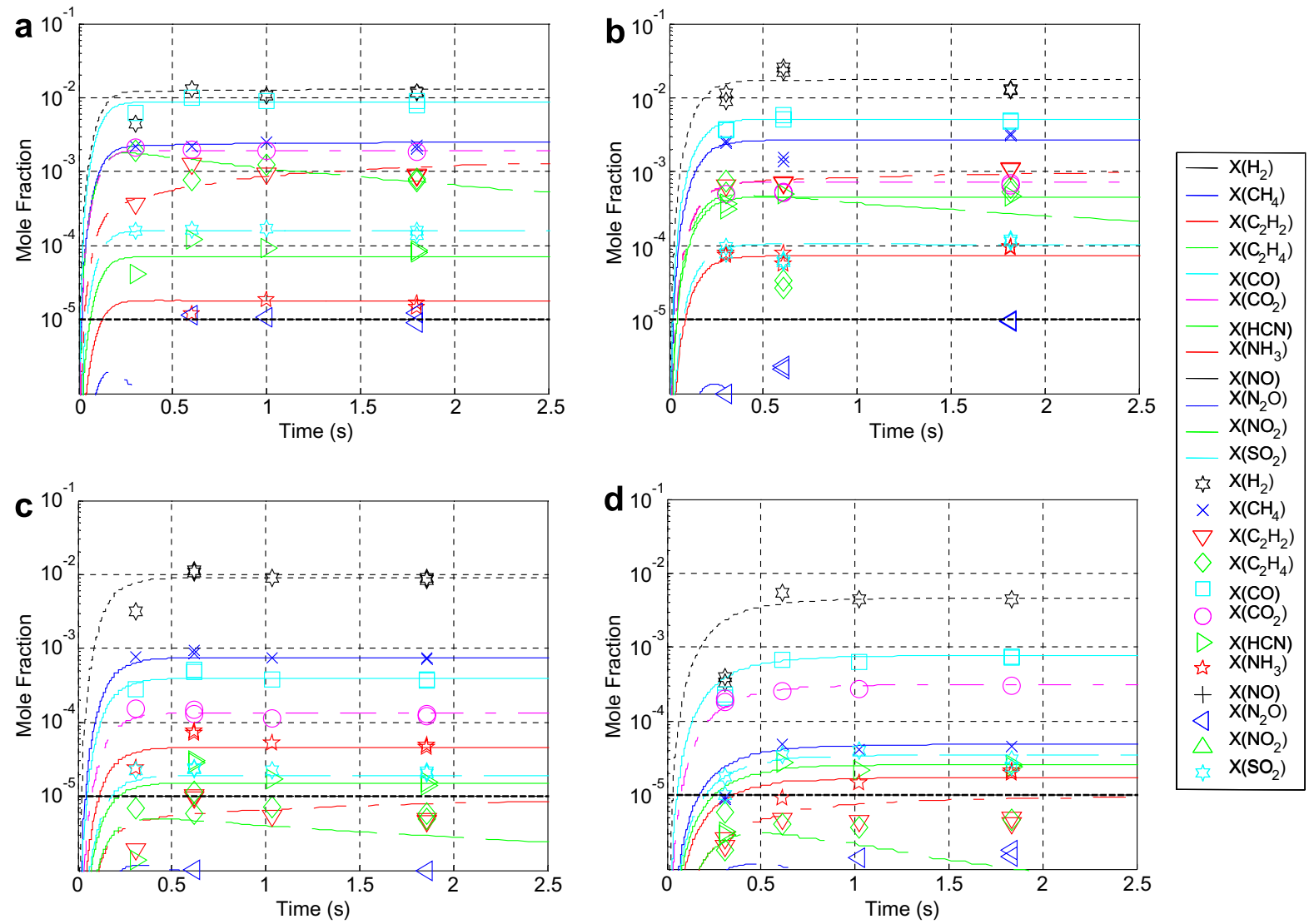

Fig. 7. Fuel devolatilisation: measured (symbols) and model predicted (curves) concentration profiles (in ppmv) at $1000{ }^{\circ} \mathrm{C}$ as a function of particle residence time. (a) Lignite; (b) coal; (c) anthracite; and (d) petcoke. 

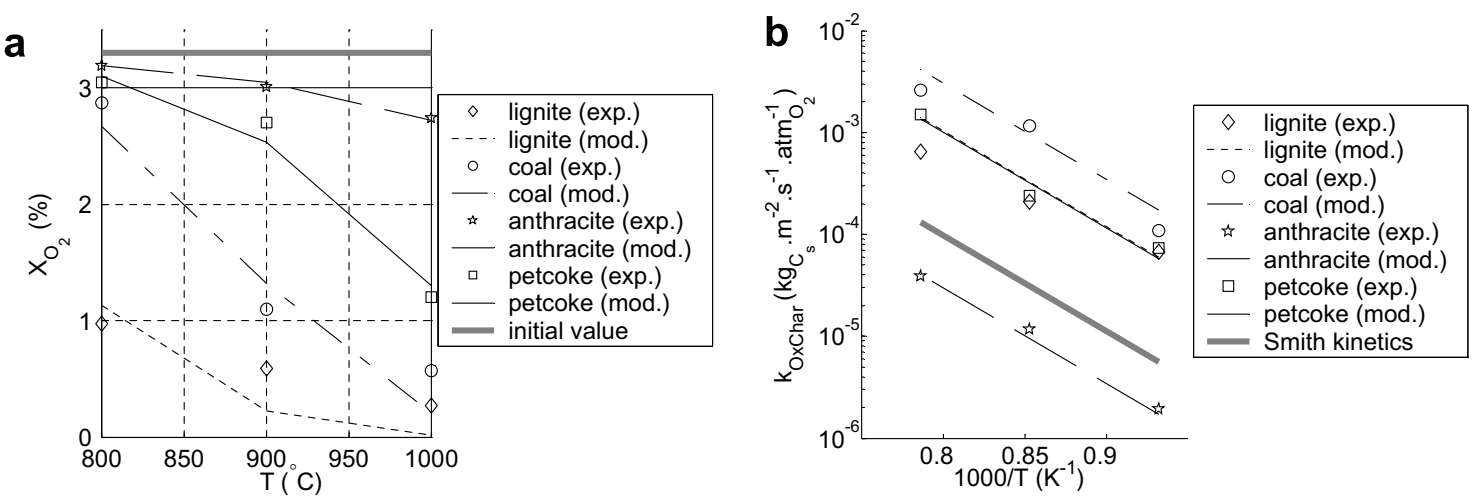

Fig. 8. Char oxidation: (a) $\mathrm{O}_{2}$ mole fraction decrease vs. temperature; (b) Arrhenius diagram for char oxidation based on BET surface; symbols are experimental values and lines are model predicted values.

hydrocarbons like $\mathrm{C}_{2} \mathrm{H}_{2}$ and $\mathrm{C}_{2} \mathrm{H}_{4}$. Their concentration varies along time, suggesting that $\mathrm{C}_{2} \mathrm{H}_{4}$ yields $\mathrm{C}_{2} \mathrm{H}_{2}$ and $\mathrm{H}_{2}$. The nitrogen species, $\mathrm{HCN}$ and $\mathrm{NH}_{3}$, are also released. These results are in close agreement with other experimental results presented in the literature $[13-17,45,46]$. It should be noted here that no NO is released during the pyrolysis.

The partitioning coefficients - that were adjusted to match the measured mole fraction for experiments at the three temperatures - are presented in Table 3.

\subsubsection{Type 2: char oxidation}

The experimental and modeling results are compared in Fig. 8. The kinetic parameters derived from this modeling are summarized in Table 3. Coal and lignite chars, which were fed at the feeding rate of $0.5 \mathrm{~g} / \mathrm{min}$, consumed more oxygen than anthracite and petcoke chars, injected at a higher rate of $1.5 \mathrm{~g} / \mathrm{min}$. The lignite char is the most reactive one; anthracite char is the less reactive char (see Fig. 8a).

The Arrhenius diagram presented in Fig. 8b shows the kinetic constant $k_{\text {OxChar }}$ for the four fuel chars; it was calculated on base of the BET surface. It appears that the reactivity of coal char is two orders of magnitude higher than that of anthracite char. Lignite and petcoke are superposed.

These experiments give interesting information about by-products from char oxidation. During oxidation, $\mathrm{SO}_{2}$ and nitrogen species $\left(\mathrm{NO}, \mathrm{NO}_{2}, \mathrm{~N}_{2} \mathrm{O}, \mathrm{NH}_{3}, \mathrm{HCN}\right)$ are also released in the gas phase. These measured concentrations allow the char oxidation partitioning coefficients (presented in Table 3) to be set in the model for the case of NO. The other measured gas concentrations are below the detection limit of $10 \mathrm{ppm}$.

\subsubsection{Type 3: NO reduction by char}

The experimental results and calculated values are plotted in terms of NO concentration in Fig. 9a and an Arrhenius diagram in Fig. 9b. The derived kinetic parameters are presented in Table 3. A close agreement between the calculated values and the experimental results was found. The activation energy initially outlined by Aarna and Suuberg [30] is once again confirmed.

The lignite char is the most reactive one; petcoke and anthracite chars are less reactive (see Fig. 9a). Coal and lignite chars (the latter fed at the rate of $0.5 \mathrm{~g} / \mathrm{min}$ ) are more efficient in reducing NO than anthracite and petcoke chars.

The specific surface related reactivity presented in an Arrhenius diagram in Fig. 9b shows that coal char is the
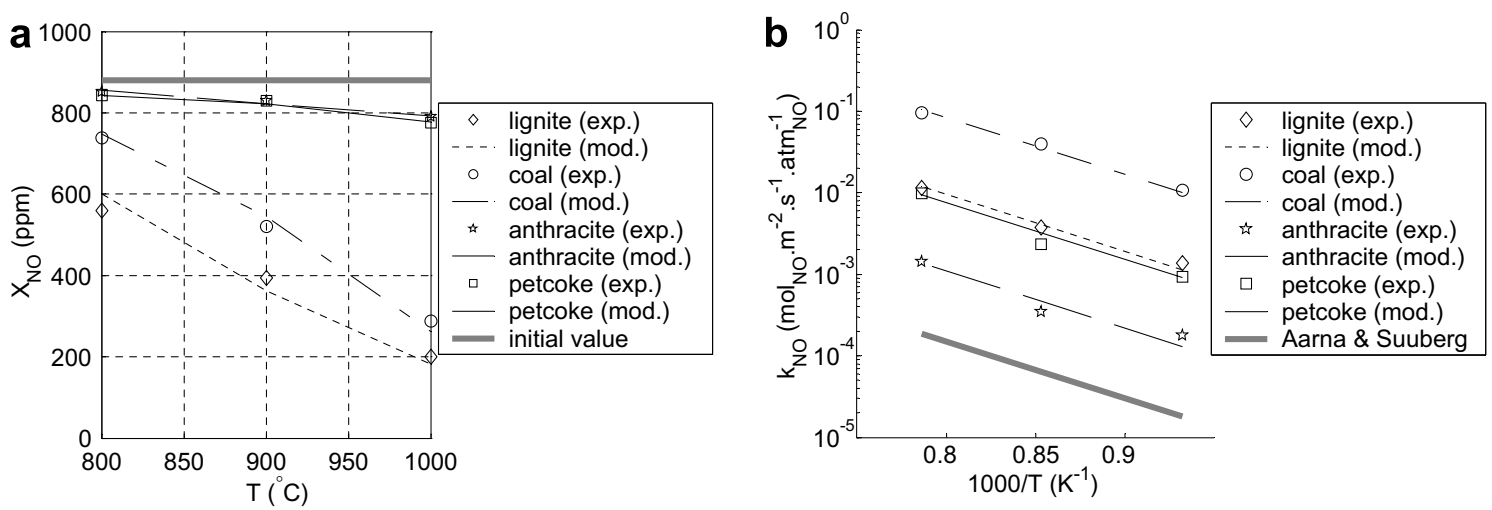

Fig. 9. NO reduction by char: (a) NO mole fraction decrease vs. temperature; (b) Arrhenius diagram for NO reduction by char based on BET surface; symbols are experiments values lines are model values. 


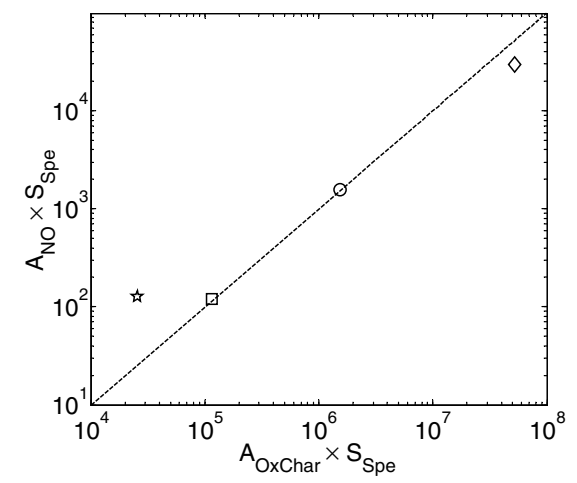

Fig. 10. $A_{\mathrm{NO}} \times S_{\mathrm{Spe}}$ in function of $A_{\mathrm{OxChar}} \times S_{\mathrm{Spe}}$ for the four fuels. Symbols: $\diamond$ lignite; $\bigcirc$ coal; ts anthracite and $\square$ petcoke.

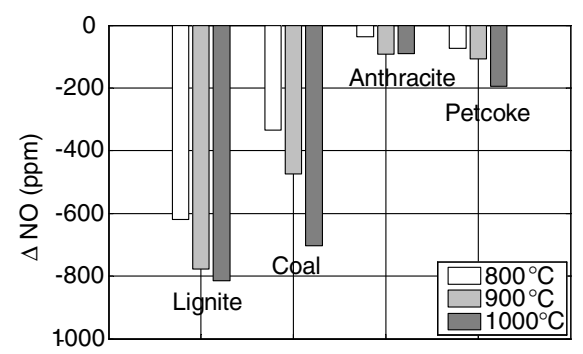

Fig. 11. NO reduction after $2 \mathrm{~s}$ residence time during reburning experiments (Type 4) at 800,900 and $1000{ }^{\circ} \mathrm{C}$ for the four fuels.
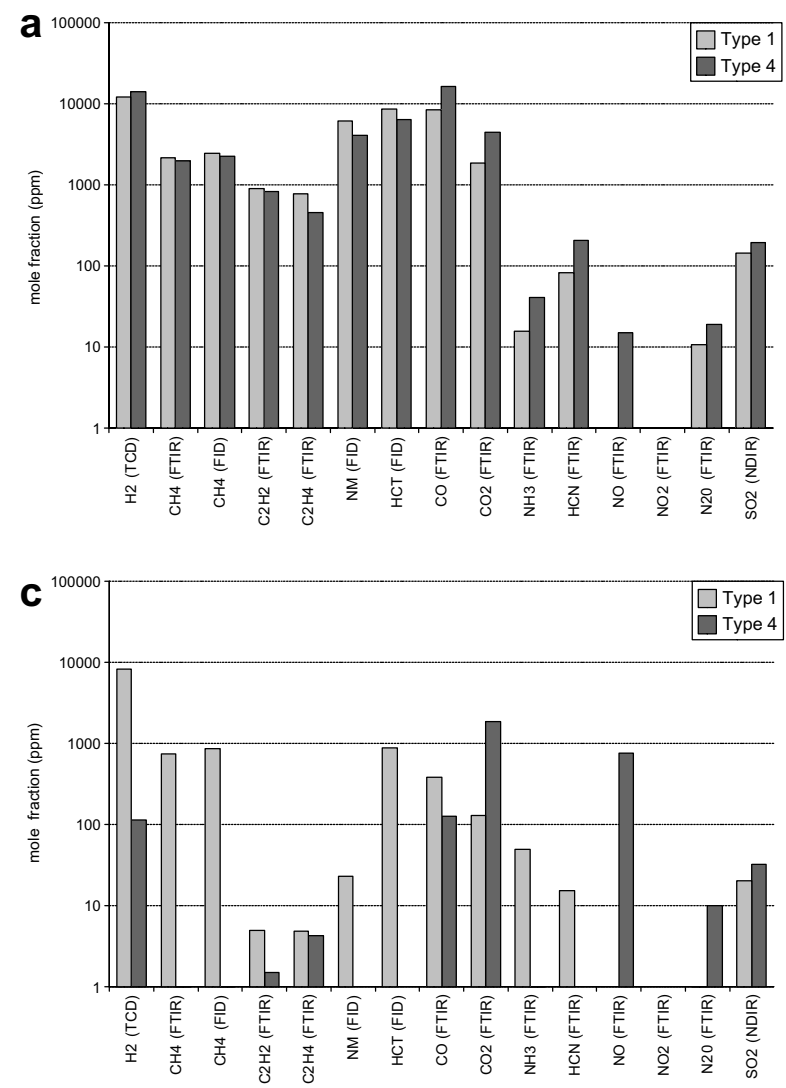

most reactive, and anthracite char the less reactive. Two orders of magnitude separate the reactivities of coal char and anthracite char.

It is interesting to compare the reactivity of the four chars to $\mathrm{O}_{2}$ on the one hand, and to $\mathrm{NO}$ on the other hand, expressed through the $\mathrm{C}_{\mathrm{s}}$ consumption kinetics. Eqs. (6) and (9) show that this carbon consumption is proportional to the product $A \times S_{\mathrm{Spe}}$. We have plotted in Fig. 10 the product $A_{\mathrm{NO}} \times S_{\mathrm{Spe}}$ vs. $A_{\mathrm{O}_{2}} \times S_{\mathrm{Spe}}$. A clear correlation between the reactivity of chars to $\mathrm{O}_{2}$ and to $\mathrm{NO}$ is drawn. The reactivity of $\mathrm{C}_{\mathrm{s}}$ to $\mathrm{O}_{2}$ is approximately 1000 times higher than the reactivity to NO. It appears that the reactivities increase with decreasing fuel rank. However, these relations should be handled with care due to the small number of fuel samples.

\subsection{Investigation of the reburning by solid fuels}

Reburning experiments were performed with the four fuels. The measured NO consumption at the three experimental temperatures was plotted in Fig. 11. This consumption is expressed as the difference between the initial and the final NO mole fraction in the gas phase. It appears clearly that lignite and coal are more efficient in reducing NO than the two low volatile fuels. Lignite is the more efficient NO reducer, whereas anthracite is the less efficient
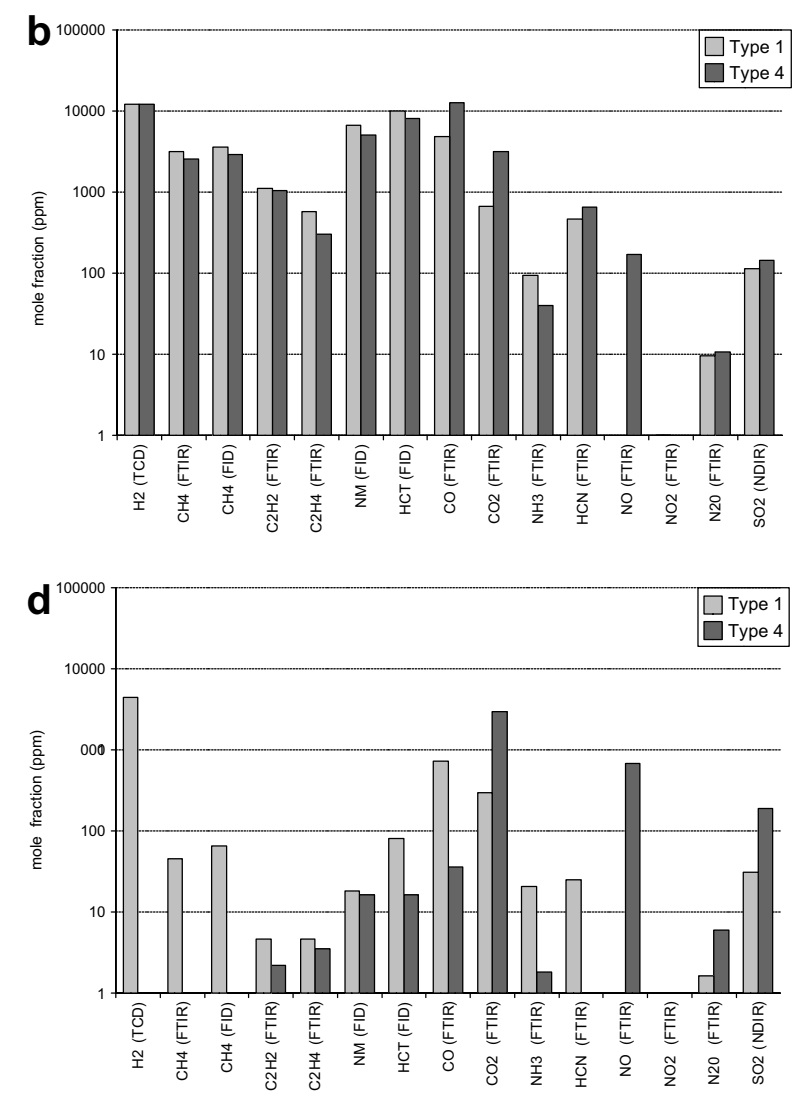

Fig. 12. Composition of the gas phase for the devolatilisation (Type 1) and reburning (Type 4) experiments types at $1000{ }^{\circ} \mathrm{C}$; NM: non-methane hydrocarbons, HCT: total hydrocarbons. (a) Lignite; (b) coal; (c) anthracite; and (d) petcoke. 
fuel. The NO reduction increases with temperature for all fuels, but not with comparable sensitivities.

The composition of the gas phase after $2 \mathrm{~s}$ particles residence time for Type 1 (devolatilisation alone) and Type 4 (devolatilisation in the presence of $1.5 \% \mathrm{O}_{2}$ and $880 \mathrm{ppm}$ NO) experiments at $1000{ }^{\circ} \mathrm{C}$ are plotted together in Fig. 12. One can see that in the case of high volatile fuels - lignite and coal - the gas phase composition is relatively stable between Type 1 and Type 4 experiments. In the case of low volatile fuels - petcoke and anthracite - hydrocarbons are no longer present in the gas phase at the end of Type 4 experiments. This can be simply explained by the fact that in the case of low VM fuels, oxygen is in excess and can oxidize the VM, which is not the case for high VM fuels.

Another very interesting result clearly appears in Fig. 12: the concentration of ethylene $\left(\mathrm{C}_{2} \mathrm{H}_{4}\right)$ and acetylene $\left(\mathrm{C}_{2} \mathrm{H}_{2}\right)$ are much lower for anthracite (ca. $\left.7 \mathrm{ppm}\right)$, and petcoke (ca. $7 \mathrm{ppm}$ ) than for lignite (ca. $1000 \mathrm{ppm}$ ) and coal (ca. $600 \mathrm{ppm}$ ). As demonstrated previously, these $\mathrm{C}_{2}$ hydrocarbons are very efficient reburning fuels [22,24,5658]. Ammonia is also released through the pyrolysis of the selected fuels at a concentration of ca. 20-100 ppm.
Since these levels are much lower than that of the NO used here $(880 \mathrm{ppm})$, the reduction of NO by ammonia cannot be efficient, as also observed by other authors [57,59].

Finally, Type 4 experiments (devolatilisation under $1.5 \%$ $\mathrm{O}_{2}$ and $880 \mathrm{ppm}$ NO) were modeled. At this step, no more parameters were adjusted. The model predicted total NO variations (white bars) are represented in Fig. 13 at the three experimental temperatures, and can be compared with experimental data (symbols). The model predicted that NO reduction capability for each fuel would increase with temperature, despite this tendency is not clear in the case of coal. A relatively close agreement between the computed and the experimental values was obtained. The model is able to describe the large differences in NO reduction capacity of the four fuels. Nevertheless, the computation seems to underestimate the NO reduction in most cases. This could be due to the fact that the model does not take into account a quantity of non-measured species that may influence the NO reduction process, particularly tars that were described in the model as $\mathrm{C}_{\mathrm{s}}$. It is also possible that the chars used for the kinetic characterization of the NO reduction by char have undergone thermal deactivation during their preparation.
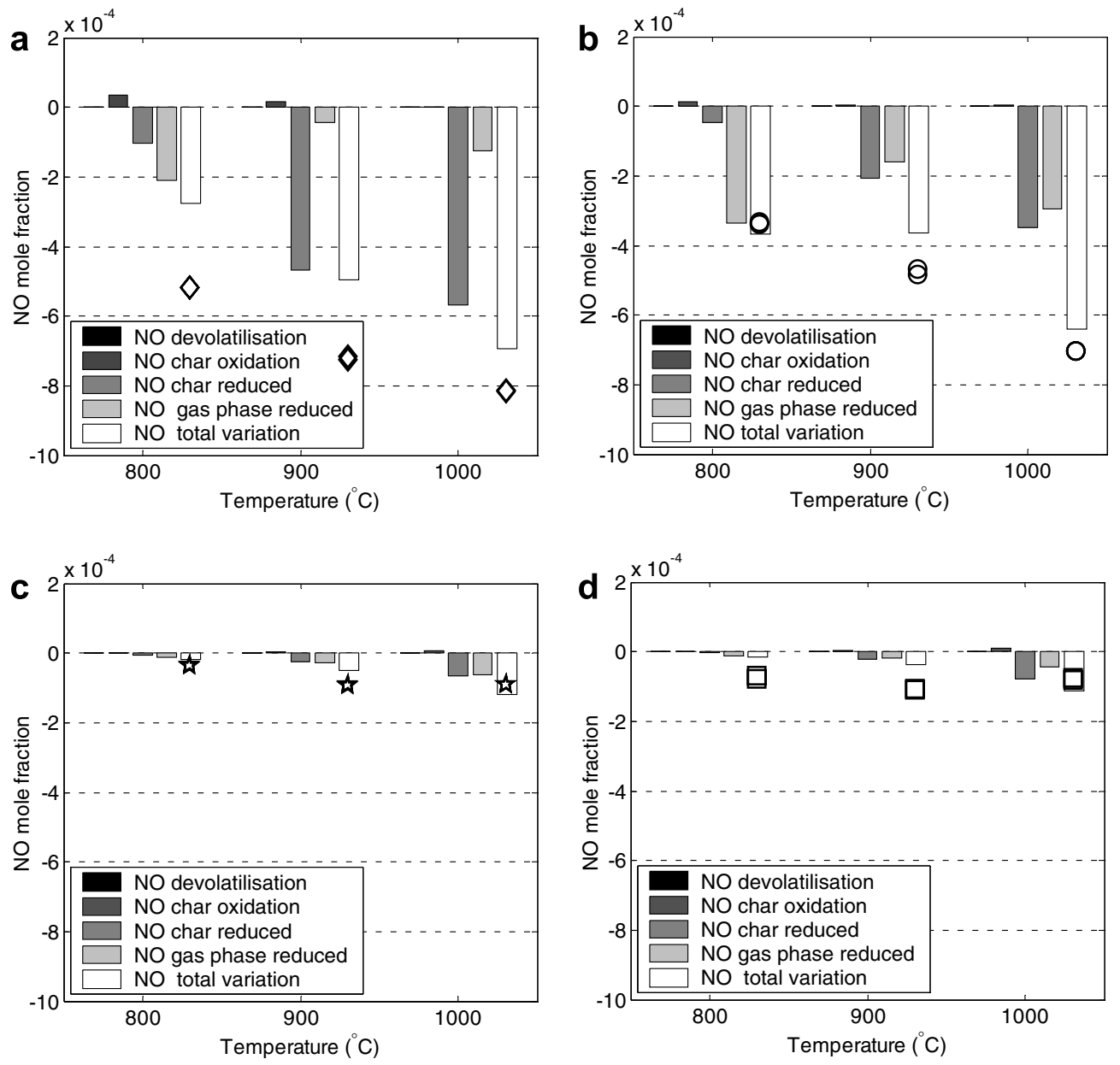

Fig. 13. Total NO mole fraction variation in the gas phase as the sum of NO from devolatilisation, from the char oxidation, reduced by char and from the gas phase reactions, at 800,900 and $1000^{\circ} \mathrm{C}$. (a) Lignite; (b) coal; (c) anthracite; and (d) petcoke; $\diamond, \bigcirc$, $\downarrow$, and $\square$ are experimental values. 
In Fig. 13 are also plotted separately the model calculated contributions of devolatilisation (black bars), char oxidation (dark grey bars), reduction at the char surface (medium grey bars) and gas phase reactions (light grey bars) to NO formation. As seen previously, NO formed during devolatilisation is negligible. The char oxidation reaction produces directly some $\mathrm{NO}$, but these quantities remain low.

Due to the direct influence of temperature on Arrhenius kinetics, the reduction of NO by char increased with temperature in all cases.

The gas phase reduction contribution increased slightly with temperature for low-volatile fuels, whereas the tendency is difficult to interpret in the case of lignite and coal. Indeed, one can see a low value at $900{ }^{\circ} \mathrm{C}$ for coal and lignite. In the case of lignite, one may recall that the total volatile mass analyzed at $900{ }^{\circ} \mathrm{C}$ was approximately half of that measured at 800 or $1000{ }^{\circ} \mathrm{C}$ (Fig. 6a). This has an influence here.

It can also be noticed that the quantity of NO produced during the char oxidation decreases with increasing temperatures for lignite and coal, whereas it increases with increasing temperatures for anthracite and petcoke
(Fig. 13c and d). In the model, the NO produced by the char oxidation is proportional to the char oxidation progress (through the coefficient $\eta_{\mathrm{c}}$ in Fig. 4). The explanation is that, in the case of lignite and coal, the particle is less oxidized with increasing temperature because oxygen is consumed by reaction with the highly reactive VM before oxidizing the char.

The non-monotonic behavior of the homogeneous NO reduction observed for lignite and coal is the result of complex competitive phenomena in the gas phase and at the char surface. A more detailed analysis of the gas-phase detailed chemistry is underway and should clarify these issues.

Fig. 14 represents the time evolution of the total NO mole fraction in the gas phase. The contributions of gas phase reactions and all heterogeneous reactions in forming/reducing NO is also represented. It can be observed from these figures that the homogeneous (gas phase) reduction process starts quickly $(0.05-0.1 \mathrm{~s})$ and then stops, whereas char NO reduction starts later on $(0.1-0.5 \mathrm{~s})$ but then always progresses.

For coal, anthracite and petcoke, the gas phase NO reduction is of the same order of magnitude as the char
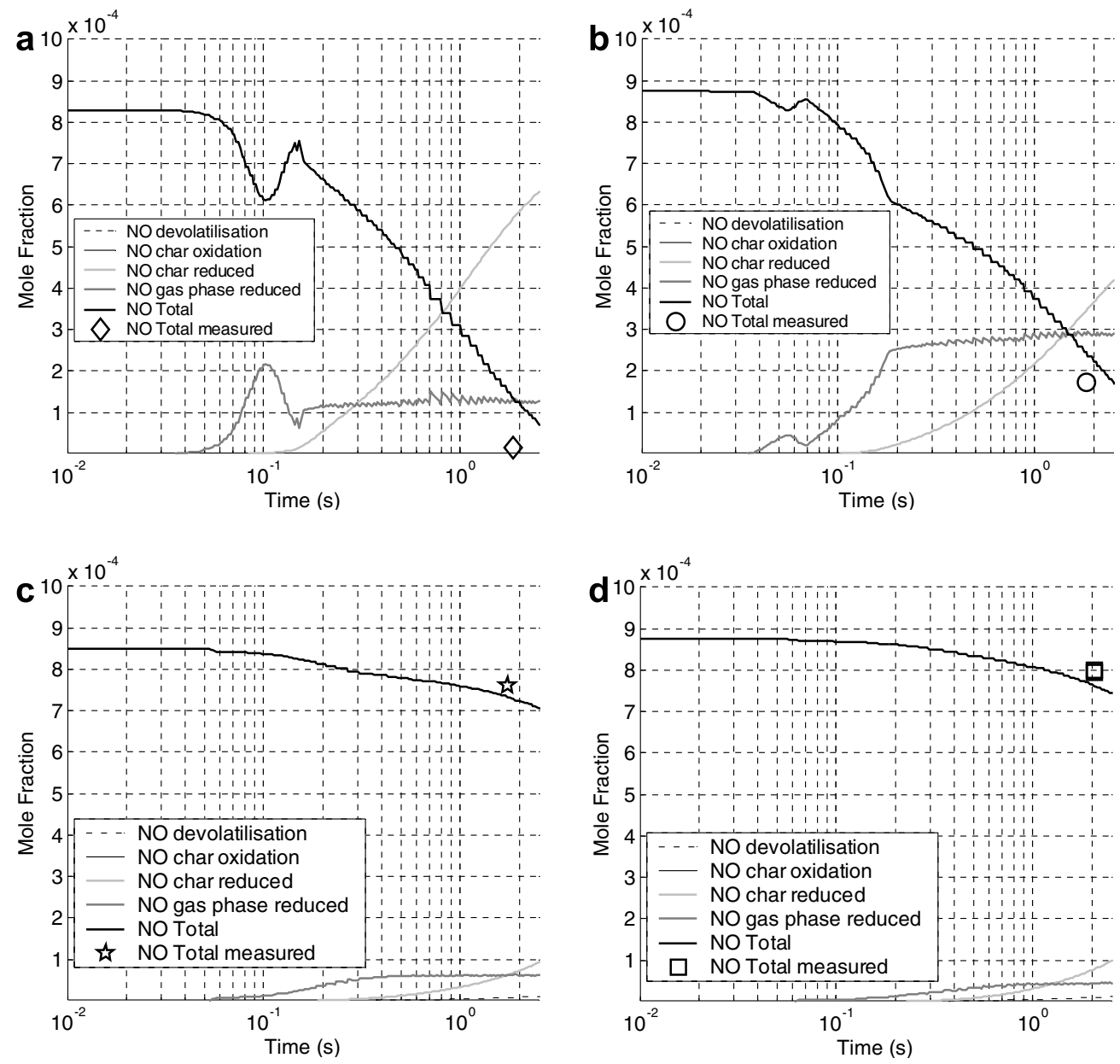

Fig. 14. Modeled time evolution of total NO mole fraction as the sum of NO from char oxidation, from the gas phase reactions, from the devolatilisation and reduced by char at $1000{ }^{\circ} \mathrm{C}$ vs. particle residence time. (a) Lignite; (b) coal; (c) anthracite; and (d) petcoke; $\diamond$, $\bigcirc, \vec{s}$ and $\square$ are experimental values. 
reduction. In the case of lignite, the homogeneous reduction starts very early but reaches a peak value and then decreases. The majority of NO decrease is due to heterogeneous reduction.

\section{Conclusion}

This work is an attempt to model a very complex process - NO reburning by solid fuels - that involves different phenomena occurring simultaneously. The NO reduction capacity of four major solid fuels were studied and explained in this work, despite several strong assumptions were necessary and could be improved.

Each phenomenon was successfully characterized separately, using the same experimental device and modeled using the same model.

- Type 1 experiments, where the fuels were pyrolysed under $100 \% \mathrm{~N}_{2}$, allowed the variety of the species released and the kinetics of the devolatilisation reaction to be quantified. This was achieved at three temperatures: 800,900 and $1000{ }^{\circ} \mathrm{C}$.

- In Type 2 experiments, the char oxidation reaction kinetics were characterized by running experiments with previously prepared chars under $3 \% \mathrm{O}_{2}$. The release of $\mathrm{N}$ - and S-containing gas species was characterized. Very large differences in reactivity of the chars from the four fuels towards $\mathrm{O}_{2}$ were observed.

- In Type 3 experiments, the char NO reduction reaction was investigated. The kinetic parameters were determined. This time also, very large differences in reactivity of the chars from the four fuels towards NO were observed.

A clear correlation between the char reactivity to $\mathrm{O}_{2}$ and the char reactivity to $\mathrm{NO}$ was found. It appears also that reactivity to $\mathrm{O}_{2}$ and to $\mathrm{NO}$ are inversely correlated to the fuel rank.

Finally, experiments were undertaken to represent the reburning conditions encountered in a cement plant calciner. Lignite is the most efficient NO reducer; this can be explained by a number of results: it has the highest volatile matter content, the highest char porous surface and its char is the most reactive towards NO. Anthracite is the worst NO-reducer; this can be explained by its low volatile content and its low char NO reduction reactivity. Coal, that also has a high volatile content and a high char reactivity, reduces NO efficiently. Petcoke is comparable to anthracite regarding its low efficiency in reducing NO.

The second part of this work concerned the modeling of the experiments. The model, once adjusted to the specific sets of experiments (Types 1, 2 and 3), enabled to analyze the complex situation of reburning by solid fuels as it occurs in a cement plant. The results clearly indicated that at short residence time, homogeneous reduction is the most efficient mechanism. After $2 \mathrm{~s}$, the char reduction mechanism becomes more significant. For three fuels - coal, anthracite and petcoke - homogeneous reduction is comparable with heterogeneous reduction. In the case of lignite, char is by far more efficient in reducing NO than gas phase reactions.

Further work will be to examine into details the mechanisms involved in the gas phase, as predicted from the detailed reaction scheme used in the model.

\section{References}

[1] Iliuta I et al. Modeling of in-line low-NOx calciners - a parametric study. Chem Eng Sci 2002;57:789-803.

[2] Commandré JM. Formation des oxydes d'azote lors de la combustion de cokes de pétrole dans des conditions de précalcinateur de cimenterie, Ph.D. Thesis, Albi, France, 2002.

[3] Pillet S. Réalisation d'un système expérimental pour caractériser la combustion et les émissions d'oxydes d'azote des combustibles solides: application aux charbons et à la biomasse, Ph.D. Thesis, Orléans, France, 2004.

[4] Smoot LD, Hill SC, Xu H. NOx control through reburning. Prog Energy Combust Sci 1998;24:385-408.

[5] Glarborg P, Jensen AD, Johnsson JE. Fuel nitrogen conversion in solid fuel fired systems. Prog Energy Combust Sci 2003:89-113.

[6] Jones JM et al. Approches to modelling heterogeneous char NO formation/destruction during pulverised coal combustion. Carbon 1999;37:1545-52.

[7] Warnatz J, Maas U, Dibble RW. Combustion. Berlin: Springer; 1999.

[8] Iliuta I, Dam-Johansen K, Jensen LS. Mathematical modeling of an in-line low NOx calciner. Chem Eng Sci 2002;57:805-20.

[9] Jensen LS. NOx from cement production - reduction by primary measures, Ph.D. Thesis, Lyngby, Denmark, 1999.

[10] Rüdiger $\mathrm{H}$ et al. Distribution of fuel nitrogen in pyrolysis products used for reburning. Fuel 1997;76:201-5.

[11] Cadavid F. Simulation numérique de la réaction des émissions de NOx dans un four pilote de $4 \mathrm{MW}$ et une chaudière tangentielle de $609 \mathrm{MW}$ à charbon pulvérisé, Ph.D. Thesis, Douai, France, 2004.

[12] Hampartsoumian E et al. Optimisation of NOx reduction in advanced coal reburning systems and the effect of coal type. Fuel 2003;82:373-84

[13] Suuberg EM, Peter WA, Howard JB. Product compositions and formation kinetics in rapid pyrolysis of pulverised coal - implications for combustions. In: 17th international symposium on combustion; 1978. p. 117-30.

[14] Serio MA et al. Kinetics of volatile product evolution in coal pyrolysis: Experiment and theory. Energy Fuels 1987:138-52.

[15] Serio MA, Peters WA, Howard JB. Kinetics of vapor-phase secondary reactions of prompt coal pyrolysis tars. Ind Eng Chem Res 1987;26:1831-8.

[16] Solomon PR, Serio AM, Suuberg EM. Coal pyrolysis: experiments, kinetic rates and mechanisms. Prog Energy Combust Sci 1992;18:133-220.

[17] Cho S, Marlow D, Niksa S. Burning velocities of multicomponent organic fuel mixtures derived from various coals. Combust Flame 1995; 101:399-410.

[18] Cho S, Niksa S. Elementary reaction models and correlations for burning velocities of multicomponent organic fuel mixtures. Combust Flame 1995;101:411-27.

[19] Perry ST, Fletcher TH. Modeling nitrogen evolution during coal pyrolysis based on a global free-radical mechanism. Energy Fuels 2000;14:1094-102.

[20] Nelson PF, Buckley AN, Kelly MD. Functional forms of nitrogen in coals and the release of coal nitrogen as NOx precursors (HCN and $\mathrm{NH}_{3}$ ). In: 24th international symposium on combustion; 1992. p. 1259-67. 
[21] Miller JA, Bowman CT. Mechanism and modelling of nitrogen chemistry in combustion. Prog Energy Combust Sci 1989;15:287-338.

[22] Dagaut P. The kinetics of hydrocarbons-NO interactions in relation with reburning. In: Trends in physical chemistry, Vol. 7. Trivandrum, India: Research Trends; 1999. p. 25-46.

[23] Dagaut P, Lecomte F. Experimental and kinetic modeling study of the reduction of $\mathrm{NO}$ by hydrocarbons and interactions with $\mathrm{SO}_{2}$ at $1 \mathrm{~atm}$. Fuel 2003;82:1033-40.

[24] Dagaut P et al. Experimental and kinetic modeling of nitric oxide reduction by acetylene in an atmospheric pressure jet-stirred reactor. Fuel 1999;78:1245-52.

[25] Dagaut P, Luche J, Cathonnet M. The kinetics of $\mathrm{C} 1$ to $\mathrm{C} 4$ hydrocarbons/NO interactions in relation with reburning. In: 28th international symposium on combustion; 2000. p. 2459-65.

[26] Dagaut P, Luche J, Cathonnet M. Experimental and kinetic modeling of the reduction of $\mathrm{NO}$ by propene at $1 \mathrm{~atm}$. Combust Flame 2000;121:651-61.

[27] Alzueta MU, Glarborg P, Dam-Johansen K. Low temperature interactions between hydrocarbons and nitric oxide: an experimental study. Combust Flame 1997;109:25-36.

[28] Glarborg P et al. Kinetic modeling of hydrocarbon/nitric oxide Interactions in a flow reactor. Combust Flame 1998;115:1-27.

[29] Miller JA, Durant JL, Glarborg P. Some chemical kinetics issues in reburning: the branching fraction of the $\mathrm{HCCO}+\mathrm{NO}$ reaction. In: 27th international symposium on combustion; 1998. p. 235-43.

[30] Aarna I, Suuberg EM. A review of the kinetics of the nitric oxydecarbone reaction. Fuel 1997;76:475-91.

[31] Commandré JM, Stanmore BR, Salvador S. The high temperature reaction of carbon with nitric oxide. Combust Flame 2002;128:211-6.

[32] Garijo EG, Jensen AD, Glarborg P. Reactivity of coal char in reducing NO. Combust Flame 2004;136:249-53.

[33] Molina A et al. Nitric oxide destruction during coal and char oxidation under pulverized-coal combustion conditions. Combust Flame 2004;136:303-12.

[34] Van de Steene L. Thermochimie de la combustion à basses températures de solides pulvérisés: application à un charbon, Ph.D. Thesis, Albi, France, 1999.

[35] Commandré JM et al. The formation and reduction of NO during the combustion of powdered petroleum coke - the case of cement plant precalciner conditions. Combust Sci Technol 2005;177:579-611.

[36] Kee RJ, Rupley FM, Miller JA. CHEMKIN II: a fotran chemical kinetics package for the analysis of the gas-phase chemical kinetics. SAND87-89-8009, Sandia Nat. Lab.; 1989.

[37] Van de Steene L, Salvador S, Charnay G. Controlling powdered fuel combustion at low temperature in a new entrained flow reactor: laboratory experiments and modelling. Combust Sci Technol 2000;159:255-79.

[38] Commandré JM, Salvador S. Lack of correlation between the properties of a petroleum coke and its behaviour during combustion. Fuel Process Technol 2005;86:795-808.
[39] AFNOR, NF M03-003 - combustibles minéraux solides - Détermination du taux de cendres; 1994.

[40] AFNOR, NF M03-004 - combustibles minéraux solides - Détermination de l'indice de matières volatiles du charbon et du coke; 2003.

[41] AFNOR, NF M03-002 - combustibles minéraux solides - Détermination de l'humidité; 1995

[42] Mermoud $\mathrm{F}$ et al. Influence of the pyrolysis heating rate on the steam gasification rate of large wood char particles. Fuel 2006;85:1473-82.

[43] Cancès J. NOx formation and reduction by a coal, a lignite, an anthracite and a petroleum coke in conditions of cement plant calciner, Ph.D. Thesis, Albi, France, 2006.

[44] Salvador $\mathrm{S}$ et al. The catalytic effect of vanadium on the reactivity of petroleum cokes with NO. Energy Fuels 2004;18:296-301.

[45] Solomon PR et al. General model of coal devolatilization. Energy Fuels 1988:405-22.

[46] Smith KL, Smoot LD, Fletcher TH. 3 - Coal characteristics, structure, and reaction rates. In: Smoot LD, editor. Fundamental of coal combustion for clean and efficient use; 1993. p. 131-298.

[47] Williams A, Pourkashanian M, Jones JM. Combustion of pulverised coal and biomass. Prog Energy Combust Sci 2001;27:587-610.

[48] Kobayashi H, Howard JB, Sarofim AF. Coal devolatilisation at high temperatures. In: 16th international symposium on combustion; 1976. p. $441-95$.

[49] Gururajan VS, Wall TF, Truelove JS. The combustion of evolved volatile matter in the vicinity of a coal particle - an evolution of the diffusion limited model. Combust Flame 1988;72:1-12.

[50] Smith IW. The intrinsic reactivity of carbons to oxygen. Fuel 1978;57:409-14.

[51] Smith IW. The combustion rates of coal chars: a review. In: 19th international symposium on combustion; 1982. p. 1045-65.

[52] Thiele EW. Relation between catalytic activity and size of particle. Ind Eng Chem 1939:31:916-20.

[53] Fogler HS. Element Chem React Eng 1999:738-808.

[54] Aarna I, Suuberg EM. Changes in reactive surface area and porosity during char oxidation. In: 27 th international symposium on combustion; 1998. p. 2933-9.

[55] Dagaut P. On the kinetics of hydrocarbons oxidation from natural gas to kerosene and diesel fuel. Phys Chem Chem Phys 2002:2079-94.

[56] Dagaut P et al. The reduction of NO by ethylene in a jet-stirred reactor at $1 \mathrm{~atm}$ : experimental and kinetic modelling. Combust Flame 1999;119:494-505.

[57] Miller JA, Glarborg P. Modeling the thermal De-NO x process: Closing in on a final solution. Int J Chem Kinet 1999;31:757-65.

[58] Prada L, Miller JA. Reburning using several hydrocarbon fuels: a kinetic modeling study. Combust Sci Technol 1998;132:225-50.

[59] Dagaut P, Nicolle A. Experimental and kinetic modeling study of the effect of $\mathrm{SO}_{2}$ on the reduction of NO by ammonia. Proc. Combust. Inst 2005;30:1211-8. 